\title{
Big Data Analytics in Supply Chain Management: A Systematic Literature Review and Research Directions
}

\author{
In Lee *(D) and George Mangalaraj
}

check for updates

Citation: Lee, I.; Mangalaraj, G. Big Data Analytics in Supply Chain Management: A Systematic Literature Review and Research Directions. Big Data Cogn. Comput. 2022, 6, 17. https://doi.org/ $10.3390 /$ bdcc 6010017

Academic Editor: Carson K. Leung

Received: 30 December 2021

Accepted: 28 January 2022

Published: 1 February 2022

Publisher's Note: MDPI stays neutral with regard to jurisdictional claims in published maps and institutional affiliations.

Copyright: (C) 2022 by the authors. Licensee MDPI, Basel, Switzerland. This article is an open access article distributed under the terms and conditions of the Creative Commons Attribution (CC BY) license (https:// creativecommons.org/licenses/by/ $4.0 /)$
School of Computer Sciences, College of Business and Technology, Western Illinois University, Macomb, IL 61455, USA; g-mangalaraj@wiu.edu

* Correspondence: I-Lee@wiu.edu

\begin{abstract}
Big data analytics has been successfully used for various business functions, such as accounting, marketing, supply chain, and operations. Currently, along with the recent development in machine learning and computing infrastructure, big data analytics in the supply chain are surging in importance. In light of the great interest and evolving nature of big data analytics in supply chains, this study conducts a systematic review of existing studies in big data analytics. This study presents a framework of a systematic literature review from interdisciplinary perspectives. From the organizational perspective, this study examines the theoretical foundations and research models that explain the sustainability and performances achieved through the use of big data analytics. Then, from the technical perspective, this study analyzes types of big data analytics, techniques, algorithms, and features developed for enhanced supply chain functions. Finally, this study identifies the research gap and suggests future research directions.
\end{abstract}

Keywords: big data analytics; data analytics; supply chain management; sustainability; performances; SCOR model; predictive analytics

\section{Introduction}

The advances in data mining techniques and mobile technologies led to the explosive growth of big data analytics (BDA) across industries. BDA transforms low-value raw data into high-value information for business decision makers. The use of BDA can create benefits, such as cost savings, better decision making, and higher product and service quality [1]. BDA has been successfully used in core business functions, such as accounting, marketing, supply chain, and operations. For example, insurance companies have been using BDA and data mining to conduct more accurate policy pricing by utilizing a variety of big data available at multiple sources [2].

The supply chain has become the central organizing unit in the globalized economy [3]. In the current business environment, in which competition is among supply chain networks, businesses are confronted with the need to effectively manage increasingly extending supply chain activities beyond their boundaries [4]. BDA in the supply chains has surged in importance recently, as cloud computing allows supply chain partners to collect, transmit, store, and process an enormous amount of data economically and share the data/information in real-time. Furthermore, BDA for the supply chains demonstrates great potential for process improvement, cost reduction, and better decision making for supply chain management (SCM).

Due to the recent development in machine learning and computing infrastructure, BDA in supply chain management (SCM) is evolving rapidly. According to marketsandmarkets.com [5], the global big data market size is expected to grow from USD 138.9 billion in 2020 to USD 229.4 billion by 2025, at a compound annual growth rate (CAGR) of $10.6 \%$ during the forecast period. Among solutions, the big data analytics segment is expected to grow at the highest CAGR during the forecast period and to hold the largest market size during the forecast period. 
While BDA is a subset of data analytics, our study shows that BDA is the dominant trend in SCM. In recent years, there has been a surge in BDA research in the SCM area. Researchers have examined various aspects of the use of BDA in SCM and have published their work in diverse research outlets in various areas, such as SCM, IS, operations management, and computer science, among others. Sanders et al. [6] highlight that disparate disciplines studying SCM aspects may risk inconsistencies in findings and fragmentation of research. They call for interdisciplinary research approaches in SCM, and this study heeds to this call and undertakes a comprehensive literature review of BDA in SCM from interdisciplinary perspectives. We present a systematic literature review of research papers published between 2011 to 2021 in both management and technical journals.

The interdisciplinary perspective allows us to synthesize the existing research on both technical and organizational perspectives and contribute in many ways. First, a recent surge of research (especially in 2019-2021) in the big data analytics in the SCM areas necessitates a fresh look at the published research in this area. Hence, this study provides a contemporary view of the published BDA in the SCM research. Second, using both the top-down and bottom-up approaches identifies research trends and presents cross-cutting themes in BDA research in the SCM area. Third, this study considers both organizational and technical perspectives, as they were evident in the bibliometric analysis of existing research, allowing us to answer questions, such as the type of BDA applications for different supply chain functions of the organization. Finally, our analysis of research themes using technical and organizational perspectives also allows us to find gaps in the research and suggest future research directions. For example, in some areas, such as security and privacy, type of analytics, and inter-organizational aspects, both technical and organizational aspects are salient.

Our paper proceeds with a discussion of the methodology for the systematic literature review in Section 2, a discussion of organizational perspectives on BDA in Section 3, a discussion of technical perspectives on BDA in Section 4, a discussion of research directions in Section 5, and a conclusion in Section 6.

\section{Methodology for Systematic Literature Review of BDA in SCM}

BDA is increasingly becoming important for the SCM arena. Hence, in the recent decade, there has been a large number of published research on BDA in the SCM area, and consequently, there are many published review articles in this area. Our study reviews the research in BDA in SCM from both top-down and bottom-up perspectives and addresses some of the shortcomings of existing published research, while at the same time complementing them. Table 1 summarizes selected review articles on data analytics in the SCM area.

Examining the published literature reviews reveals the importance and diversity of BDA for SCM research. Moreover, it also reveals avenues for gaining additional insights by further reviewing the published research, and they are as follows. First, existing reviews either took technical (e.g., [7,15]) or organizational perspectives (e.g., [13,17]). However, Arunachalam et al. [18] highlight that the challenges in using BDA in SCM involve both technical and organizational aspects. Hence, an interdisciplinary perspective involving technical and organizational perspectives on the published research could provide a holistic view of the BDA in SCM research to the audience. Second, with an interdisciplinary perspective, this study included an exhaustive set of digital libraries (Scopus, Web of Science, IEEE eXplore, and ACM digital library) to scope out the research on BDA in SCM. This is unlike the prior reviews on BDA in SCM, which have relied on SCOPUS and Web of Science to a large extent, resulting in the exclusion of research-oriented towards technological aspects. This study also includes research publications from IEEE eXplore and ACM Digital Library to provide a more inclusive view of organizational and technical aspects in the BDA research in the SCM area. Third, some of the past review articles relied on specific areas in the use of big data analytics in supply chains (e.g., cold chain: [19]), or specific techniques of big data analytics in supply chain management (e.g., machine 
learning: [15]). Hence, a review of the research corpus into the whole big data analytics in SCM is warranted. Fourth, unlike past studies, where either a purely bottom-up approach using software tools (e.g., topic modeling: [20]) or a top-down approach using manual categorization (e.g., content analysis of literature: [19]), our study relies on both top-down and bottom-up approaches to synthesize the BDA research in the SCM. We use bibliometric tools to identify patterns in the research and then separately analyze selected articles using theoretical frameworks to discuss the patterns in the research.

Table 1. Selected literature review articles on data analytics.

\begin{tabular}{|c|c|c|c|c|}
\hline Paper & Topic & Source & Time Frame & Findings \\
\hline Nguyen et al. [7] & $\mathrm{BDA}$ in the SCM & $\begin{array}{c}\text { Various digital libraries } \\
\text { (Science Direct, Emeralds, } \\
\text { IEEE eXplore, Scopus, } \\
\text { EBSCO) }\end{array}$ & 2011-2016 & $\begin{array}{l}\text { Examining the areas } \\
\text { where BDA is used in } \\
\text { SCM, level of analytics } \\
\text { used, types of BDA } \\
\text { models used, and the } \\
\text { techniques used. }\end{array}$ \\
\hline Tiwari et al. [8] & BDA in the SCM & $\begin{array}{l}\text { Harzing Publish or Perish } \\
\text { software relying on } \\
\text { Google Scholar citations }\end{array}$ & 2010-2016 & $\begin{array}{l}\text { Classified research in big } \\
\text { data analytics in SCM into } \\
\text { definition and benefit; } \\
\text { application and } \\
\text { exploration; technology } \\
\text { and methods. }\end{array}$ \\
\hline Ardito et al. [9] & $\begin{array}{l}\text { BDA in business areas that } \\
\text { includes SCM using } \\
\text { bibliometric analysis }\end{array}$ & Web of Science & 2012-2017 & $\begin{array}{l}\text { Found the following } \\
\text { clusters: theoretical } \\
\text { development; } \\
\text { management transition to } \\
\text { BDA; firm resources, } \\
\text { capabilities, and } \\
\text { performance; and BDA for } \\
\text { SCM. }\end{array}$ \\
\hline Chehbi-Gamoura et al. [10] & $\begin{array}{l}\text { SCOR model with data } \\
\text { analytics in SCM }\end{array}$ & $\begin{array}{l}\text { Harzing Publish or Perish } \\
\text { software relying on } \\
\text { Google Scholar citations }\end{array}$ & 2001-2018 & $\begin{array}{c}\text { SCOR processes and BDA } \\
\text { use across different } \\
\text { journals. }\end{array}$ \\
\hline Inamdar et al. [11] & BDA adoption & Web of Science & 2014-2018 & $\begin{array}{c}\text { Seven areas of research } \\
\text { with most in } \\
\text { manufacturing and } \\
\text { service. }\end{array}$ \\
\hline Kamble and Gunasekaran [12] & $\begin{array}{l}\text { BDA and performance } \\
\text { measurement }\end{array}$ & Scopus & Up to 2018 & $\begin{array}{l}\text { Research classified into } \\
\text { performance analytics } \\
\text { capability and processes. }\end{array}$ \\
\hline Yudhistyra et al. [13] & $\begin{array}{l}\text { BDA in logistics and } \\
\text { supply chain }\end{array}$ & Scopus & 2011-2018 & $\begin{array}{c}\text { Found changing role of } \\
\text { BDA and challenges in } \\
\text { BDA. }\end{array}$ \\
\hline Ogbuke et al. [14] & BDA in the SCM & Scopus & 2005-2020 & $\begin{array}{c}\text { Qualitative review of } \\
120 \text { articles and identified } \\
7 \text { themes with } \\
14 \text { sub-themes. }\end{array}$ \\
\hline Aamer et al. [15] & $\begin{array}{c}\text { Data analytics / machine } \\
\text { learning in demand } \\
\text { forecasting of SCM }\end{array}$ & Scopus and Web of Science & 2010-2019 & $\begin{array}{c}\text { Identified neural } \\
\text { networks, artificial neural } \\
\text { networks, regression, and } \\
\text { support vector machines } \\
\text { as the most widely used } \\
\text { algorithm. }\end{array}$ \\
\hline Maheshwari et al. [16] & $\begin{array}{l}\text { BDA in SCM/logistics } \\
\text { management/inventory } \\
\text { management }\end{array}$ & Web of Science & 2015-2019 & $\begin{array}{l}\text { Found various domains } \\
\text { such as education, finance, } \\
\text { telecom, retail, healthcare, } \\
\text { and governance. }\end{array}$ \\
\hline
\end{tabular}

In order to address the shortcomings mentioned above, this study adopts the systematic literature review method proposed by Denyer and Tranfield [17] to examine the published research on BDA in the SCM area. A systematic literature review is aimed at achieving a scientific synthesis of a specific topic through a rigorous analysis of published studies. The five steps of the systematic literature review method proposed by Denyer and Tranfield [17] include (1) formation of research questions, (2) location of studies, (3) selection and evaluation of studies, (4) analysis and synthesis, and (5) presenting the 
results. For a transparent, auditable, and replicable review, this study closely follows the aforementioned five steps.

\subsection{Formation of Research Questions}

Given the fragmented literature review and rapid change of BDA, this study attempts to conduct a comprehensive literature review using the above-mentioned methodology. The first step in conducting a systematic literature review is the formation of the research questions, which should be clear to establish the focus of the study.

Based on the analysis of the above-mentioned selected literature review articles, we identified specific areas to investigate in depth. We applied CIMO (context, intervention, mechanism, and outcome) logic, suggested by Denyer et al. [21], to specify well-formulated research questions. We define the BDA in SCM as the context of this study. We identify intervention methods (e.g., types of BDA applications in SCM) and value generation mechanisms (e.g., specific ways of adopting and implementing BDA), and analyze outcomes in terms of specific performances achieved from the use of various intervention methods and mechanisms of BDA in SCM. We also identify somewhat understudied, yet promising future research directions for the research community. Specifically, the following research questions have been developed to systematically guide the literature review.

RQ1: What are theoretical views on the value generation mechanisms of BDA in SCM?

RQ2.1: What are the impacts of BDA on organizational performances?

RQ2.2: What are the impacts of BDA on sustainability?

RQ3: What types of BDA applications, architecture, and infrastructure have been used for different supply chain functions?

RQ4: What are the technical performances of BDA techniques and algorithms?

RQ5: What are the research opportunities and directions for BDA in SCM?

RQ1, RQ2.1, and RQ2.2 are addressed in Section 3. RQ3 and RQ4 are discussed in Section 4 and RQ5 is addressed in Section 5.

\subsection{Locating Studies}

Three frequently used databases for the topics related to supply chains were included for locating studies: Scopus, ACM Digital Library, and IEEE Xplore. The database queries were developed with the search interface of each database to retrieve papers related to BDA in SCM. As of 1 November 2021, the database search was limited to papers from journals published from 2011 to 2021. The systematic literature review of this paper does not include book chapters and conference papers, as some of these papers may not have gone through rigorous academic peer reviews and many high-quality papers have been published in reputed journals. The resulting search results are 320 articles from Scopus, 39 from ACM Digital Library, and 30 from IEEE Xplore. Table 2 shows query strings used in each of the databases.

\subsection{Study Selection and Evaluation}

A set of inclusion and exclusion criteria were established to select the most relevant studies among 389:

- $\quad$ Relevance to BDA in SCM

- Quality of paper: Theoretical foundations, research design, and implementation.

- Conceptual papers, literature papers, editorials, mathematical papers, or tutorial papers were excluded.

- Multiple papers with similar research models published by the same authors were excluded.

- $\quad$ Articles, the full-text of which were not accessible from the databases, were excluded.

Table 3 shows the four steps employed for the study selection, evaluation, and the number of selected papers in each step. Papers with topics on BDA were identified among the 378 articles and, on average, $60 \%$ of the 378 articles focus on BDA in SCM. Due to the 
strong interest in BDA, we decided to focus our literature review on BDA in SCM. In Step 3 , we removed 151 articles without focusing on BDA. Figure 1 shows the year-by-year frequency of the published articles, the topic of which is BDA. To strengthen the selection validity, the article selection was evaluated by the two researchers. One researcher selected articles and another checked the articles. When there was a disagreement, the researchers discussed the issues until a consensus was made for the selection of the articles.

Table 2. Query strings used in each of the three databases.

\begin{tabular}{|c|c|c|}
\hline Database & Query & Results \\
\hline $\begin{array}{c}\text { Scopus } \\
\text { https://www.scopus.com } \\
\text { Advanced search }\end{array}$ & $\begin{array}{l}\text { TITLE-ABS-KEY(“supply chain” and } \\
\text { “data analytics”) AND (LIMIT-TO } \\
\text { (SRCTYPE, “j”)) AND (LIMIT-TO } \\
\text { (PUBYEAR, 2021) OR LIMIT-TO } \\
\text { (PUBYEAR, 2020) OR LIMIT-TO } \\
\text { (PUBYEAR, 2019) OR LIMIT-TO } \\
\text { (PUBYEAR, 2018) OR LIMIT-TO } \\
\text { (PUBYEAR, 2017) OR LIMIT-TO } \\
\text { (PUBYEAR, 2016) OR LIMIT-TO } \\
\text { (PUBYEAR, 2015) OR LIMIT-TO } \\
\text { (PUBYEAR, 2014) OR LIMIT-TO } \\
\text { (PUBYEAR, 2013) OR LIMIT-TO } \\
\text { (PUBYEAR, 2012) OR LIMIT-TO } \\
\text { (PUBYEAR, 2011)) }\end{array}$ & 320 articles \\
\hline $\begin{array}{l}\text { ACM Digital Library } \\
\text { https://dl.acm.org/ } \\
\text { Advanced search }\end{array}$ & $\begin{array}{l}\text { "query": \{AllField:(“supply chain”) AND } \\
\text { AllField:(“data analytics”)\} } \\
\text { “filter": }\{\text { ACM Pub type: Journals, } \\
\text { Publication Date: (1 January } 2011 \text { TO } 31 \\
\text { December 2021), ACM Content: DL\} }\end{array}$ & 39 articles \\
\hline IEEE Xplore & $\begin{array}{l}\text { ("All Metadata":supply chain) AND } \\
\text { ("All Metadata":data analytics) } \\
\text { Filters Applied: Journals2011-2021 }\end{array}$ & 30 articles \\
\hline
\end{tabular}

Table 3. Four steps of study selection and evaluation.

\begin{tabular}{cccc}
\hline Step 1 & Step 2 & Step 3 & Step 4 \\
\hline 389 articles & 378 articles & 226 articles & $\begin{array}{c}60 \text { articles } \\
\text { Removal } 166 \text { articles with } \\
\text { inclusion and exclusion } \\
\text { criteria; selected 35 }\end{array}$ \\
$\begin{array}{c}\text { Scopus: 320; ACM Digital } \\
\text { Library: 39; IEE Xplore: 30 }\end{array}$ & $\begin{array}{c}\text { Duplicate removal of 11 } \\
\text { articles due to duplication } \\
\text { among the three databases }\end{array}$ & $\begin{array}{c}\text { Removal of 151 articles } \\
\text { without focusing on big data } \\
\text { analytics }\end{array}$ & $\begin{array}{c}\text { management-focused articles } \\
\text { and 25 technology-focused } \\
\text { articles }\end{array}$ \\
\hline
\end{tabular}

Applying duplicate removal among the database, the inclusion and exclusion criteria, and agreement between the two researchers of the selected articles, 60 articles were finally selected in Step 4. Among the 60 articles, 35 articles are related to organization perspectives and 25 articles are related to technical perspectives. 


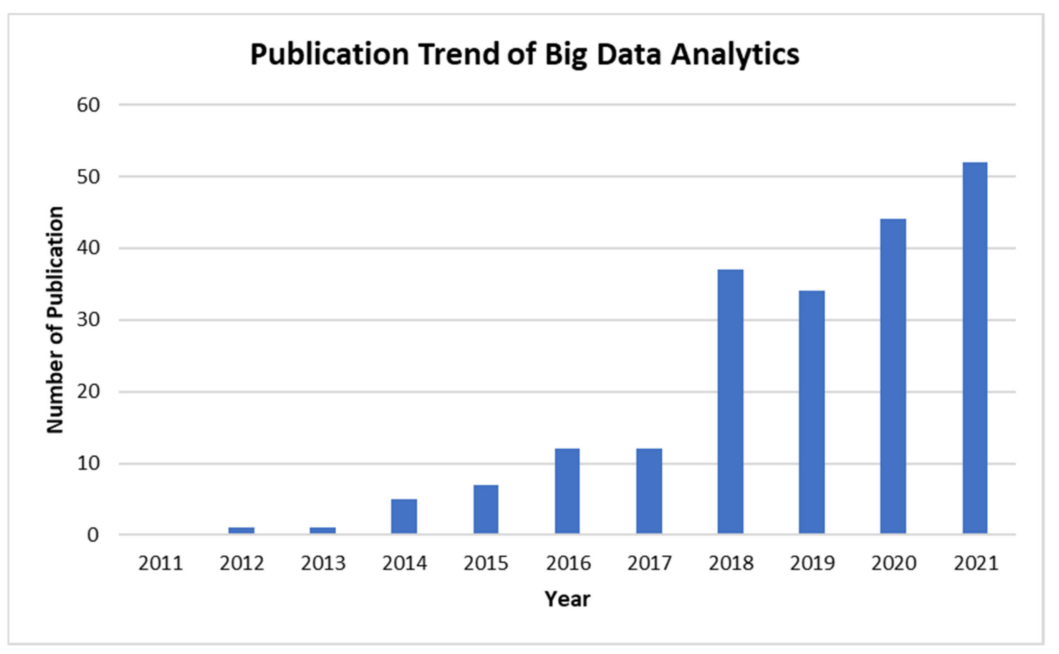

Figure 1. Publication Trend of BDA in SCM.

\subsection{Analysis and Synthesis}

The bottom-up approach employs the automated keyword analysis of the selected articles. The top-down approach is used to develop a framework of the systematic literature review based on the judgment of the authors. The keyword analysis uses VOSviewer to identify the common interests among the selected 60 articles. With at least three cooccurrences of keywords, 16 keywords were identified. Figure 2 shows the co-occurrence network of keywords.

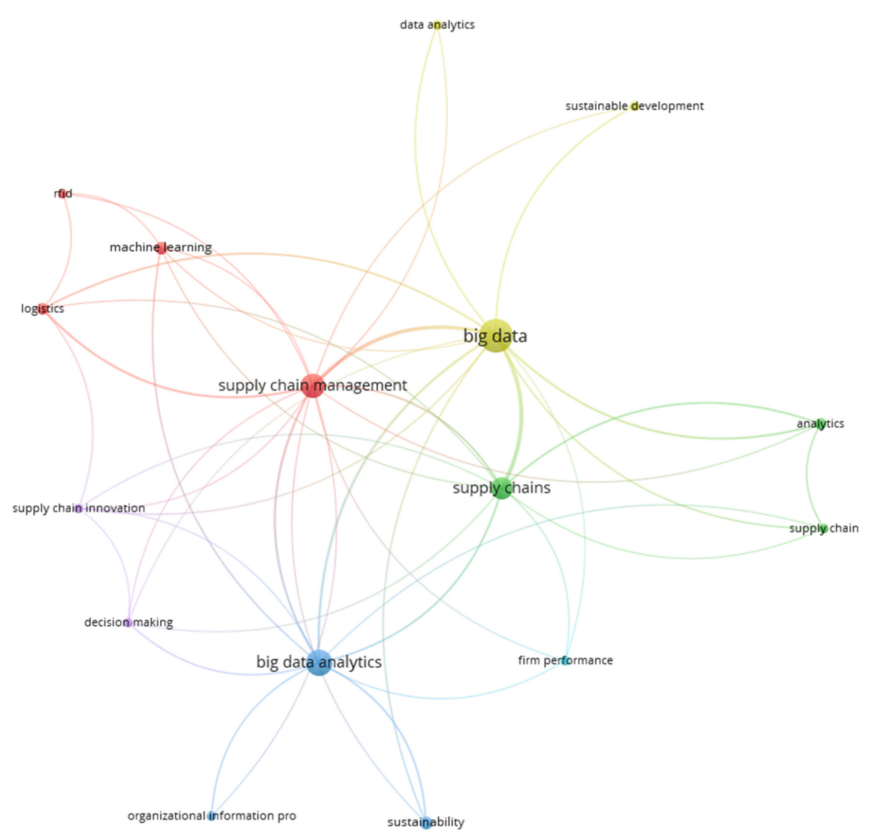

Figure 2. Word co-Occurrence analysis.

The most frequently co-occurring keywords are big data, supply chain management, big data analytics, supply chains, machine learning, analytics, decision making, sustainability, firm performance, and machine learning, etc. Based on the co-occurrence word analysis, we developed a framework of the systematic literature review, which consists of two research perspectives: organizational perspectives and technical perspectives. The organizational perspectives consist of three themes: (1) organizational performances, (2) sustainability, and (3) implementation challenges. The technical perspectives consist of two themes: (1) applications of BDA and (2) architecture/infrastructure of BDA. Fig- 
BDA in SCM? and RQ2.1: What are the impacts of BDA on organizational performances? Table 4 summarizes the authors, purpose, theories/views, and constructs/sub-constructs relevant to the theories and views of the 16 selected papers. Many theories and views developed in the fields of organization and strategy have theoretical foundations to understand the impacts of BDA on supply chains and organizational performances: dynamic capabilities view (seven papers), organizational information processing theory (OIPT) (three papers), the resource-based view (RBV) (three papers), and organizational mindfulness (one paper). The most frequently used research method is a survey (12 papers), followed by a case study (one paper), interview (one paper), and the Delphi method (one paper). The partial least square structural equations model (PLS-SEM) was the most widely used for the data analysis (10 papers), followed by regression (two papers) and interpretative structural modeling (one paper). In the following, the literature analysis of the organizational performances is divided into a dynamic capabilities view, organizational information processing theory, and resource-based view.

Table 4. Paper, purpose, theories/views, and constructs/sub-constructs of organizational performances.

\begin{tabular}{|c|c|c|c|}
\hline Paper & Purpose & $\begin{array}{l}\text { Theories/ } \\
\text { Views }\end{array}$ & $\begin{array}{c}\text { Constructs/Sub-Constructs } \\
\text { Relevant to the Theories } \\
\text { and Views }\end{array}$ \\
\hline Chen et al. [22] & $\begin{array}{l}\text { Investigate the impact of } \\
\text { organizational BDA usage on } \\
\text { business productivity and } \\
\text { growth and factors of } \\
\text { organizational BDA usage. }\end{array}$ & Dynamic capabilities & Organizational use of BDA. \\
\hline Mandal [23] & $\begin{array}{l}\text { Explore the impact of BDA } \\
\text { management capabilities on } \\
\text { supply chain resilience. }\end{array}$ & Dynamic capabilities & $\begin{array}{l}\text { BDA planning capability, } \\
\text { BDA investment decision } \\
\text { making, BDA coordination } \\
\text { capability, and BDA control. }\end{array}$ \\
\hline Wamba et al. [24] & $\begin{array}{l}\text { Investigate the role of } \\
\text { BDA-enabled dynamic } \\
\text { capability on organizational } \\
\text { performance. }\end{array}$ & Dynamic capabilities & $\begin{array}{l}\text { BDA capability: } \\
\text { sensing, seizing and } \\
\text { reconfiguring. }\end{array}$ \\
\hline Bamel \& Bamel [25] & $\begin{array}{l}\text { Identify BDA-based enablers } \\
\text { for the supply chain capability } \\
\text { and establish a hierarchy and } \\
\text { interrelationship among the } \\
\text { enablers. }\end{array}$ & Dynamic capabilities & $\begin{array}{l}\text { Financial support, people } \\
\text { skills, IT infrastructure, and } \\
\text { leadership commitment. }\end{array}$ \\
\hline Dubey et al. [26] & $\begin{array}{l}\text { Examine the development of } \\
\text { BDA capability (BDAC) to } \\
\text { improve supply chain agility } \\
\text { and achieve competitive } \\
\text { advantage. }\end{array}$ & Dynamic capabilities & $\begin{array}{c}\text { BDAC and } \\
\text { supply chain agility. }\end{array}$ \\
\hline Gu et al. [27] & $\begin{array}{l}\text { Examine the alignment } \\
\text { between BDAC and a specific } \\
\text { type of procurement strategy } \\
\text { and its impact on firm } \\
\text { performance. }\end{array}$ & Dynamic capabilities & $\mathrm{BDAC}$ \\
\hline Singh and Singh [28] & $\begin{array}{l}\text { Examine how firms can } \\
\text { develop business risk } \\
\text { resilience from supply chain } \\
\text { disruption events by } \\
\text { developing BDAC. }\end{array}$ & Dynamic capabilities & $\begin{array}{l}\text { IT infrastructure capabilities } \\
\text { and BDAC. }\end{array}$ \\
\hline
\end{tabular}


Table 4. Cont.

\begin{tabular}{|c|c|c|c|}
\hline Paper & Purpose & $\begin{array}{l}\text { Theories/ } \\
\text { Views }\end{array}$ & $\begin{array}{c}\text { Constructs/Sub-Constructs } \\
\text { Relevant to the Theories } \\
\text { and Views }\end{array}$ \\
\hline Srinivasan and Swink [29] & $\begin{array}{l}\text { Investigate associations } \\
\text { between visibility, analytics } \\
\text { capability, and flexibility. }\end{array}$ & $\begin{array}{l}\text { Organizational information } \\
\text { processing theory }\end{array}$ & $\begin{array}{l}\text { Analytics capability, demand } \\
\text { visibility, supply visibility, and } \\
\text { organizational flexibility. }\end{array}$ \\
\hline Yu et al. [30] & $\begin{array}{c}\text { Investigate the roles of BDAC } \\
\text { in hospital supply chain } \\
\text { integration and operational } \\
\text { flexibility. }\end{array}$ & $\begin{array}{l}\text { Organizational information } \\
\text { processing theory }\end{array}$ & $\begin{array}{l}\text { BDAC and three dimensions } \\
\text { of hospital supply chain } \\
\text { integration (inter-functional } \\
\text { integration, hospital-patient } \\
\text { integration, and } \\
\text { hospital-supplier integration). }\end{array}$ \\
\hline Roßmann et al. [31] & $\begin{array}{l}\text { Investigate the impact of BDA } \\
\text { on the development of SCM } \\
\text { and the organizational role of } \\
\text { supply chain managers. }\end{array}$ & $\begin{array}{l}\text { Organizational information } \\
\text { processing theory }\end{array}$ & $\begin{array}{l}\text { BDA applications and supply } \\
\text { chain transparency. }\end{array}$ \\
\hline Gunasekaran et al. [32] & $\begin{array}{l}\text { Investigate the extent to which } \\
\text { connectivity and information } \\
\text { sharing impact acceptance of } \\
\text { big data predictive analytics } \\
\text { (BDPA) and assimilation } \\
\text { capabilities and the impact of } \\
\text { BDPA assimilation on supply } \\
\text { chain performance and } \\
\text { organizational performance. }\end{array}$ & Resource-based view & $\begin{array}{l}\text { Connectivity and information } \\
\text { sharing. }\end{array}$ \\
\hline Shafique et al. [33] & $\begin{array}{l}\text { Investigate the relationship } \\
\text { between big data predictive } \\
\text { analytics (BDPA), radio } \\
\text { frequency identification } \\
\text { (RFID) technology, and supply } \\
\text { chain performance. }\end{array}$ & Resource-based view & BDPA and RFID technology. \\
\hline Fernando et al. [34] & $\begin{array}{l}\text { Investigate the effects of BDA, } \\
\text { data security, and service } \\
\text { supply chain innovation } \\
\text { capabilities on services supply } \\
\text { chain performance. }\end{array}$ & Resource-based view & $\begin{array}{l}\text { Data security infrastructure } \\
\text { and BDA infrastructure. }\end{array}$ \\
\hline Dennehy et al. [35] & $\begin{array}{l}\text { Investigate the role of BDAC } \\
\text { and organizational } \\
\text { mindfulness in resilient } \\
\text { supply chains in a disaster } \\
\text { response context. }\end{array}$ & Organizational mindfulness & $\begin{array}{l}\text { Preoccupation with failure, } \\
\text { reluctance to simplify } \\
\text { operations, sensitivity to } \\
\text { operations, commitment to } \\
\text { resilience, and deference to } \\
\text { expertise. }\end{array}$ \\
\hline Lin and Lin [36] & $\begin{array}{c}\text { Analyze how the case } \\
\text { company } \\
\text { develops a global logistics } \\
\text { service value-added system. }\end{array}$ & No specific theory/view & $\begin{array}{c}\text { Plan-Do-Check-Action } \\
\text { (PDCA) cycle and strategic } \\
\text { information systems planning. }\end{array}$ \\
\hline Jha et al. [37] & $\begin{array}{l}\text { Identify the factors that assist } \\
\text { a company in or inhibit it } \\
\text { from building its BDAC. }\end{array}$ & No specific theory/view & $\begin{array}{c}\text { Data management and use of } \\
\text { advanced software packages } \\
\text { and skilled human resources } \\
\text { and training for analytics, } \\
\text { intra-organizational power } \\
\text { dynamics, global } \\
\text { connectedness, and external } \\
\text { landscape and analytics } \\
\text { capabilities. }\end{array}$ \\
\hline
\end{tabular}




\subsubsection{Dynamic Capabilities View}

Teece et al. [38] proposed the dynamic capabilities approach to analyze the sources of wealth creation by firms. The dynamic capabilities view (DCV) suggests that private wealth creation in rapidly changing technological environments depends in a large measure on honing internal technological, organizational, and managerial processes inside the firm [38]. Eisenhardt and Martin [39] (p. 1107) defined dynamic capabilities as "the firm's processes that use resources-specifically the processes to integrate, reconfigure, gain and release resources-to match and even create market change".

Several studies on the BDA in SCM employed DCV to understand the relationship between BDA and organizational performances. For example, Chen et al. [22] conceptualized organizational use of BDA as creating dynamic capabilities. Applying the technologyorganization-environment (TOE) framework, they found that organizational and environmental factors indirectly affect organizational use of BDA through top management support, and technological factors directly affect organizational use of BDA, which in turn affects organizational value creation. Mandal [23] argued that BDA management capabilities are also dynamic capabilities that result in supply chain resilience. He found that BDA planning, BDA coordination, and BDA control are critical enablers of three supply chain resilience dimensions: supply chain preparedness, supply chain alertness, and supply chain agility.

Wamba et al. [24] conceptualized the dynamic capabilities of BDA as a multi-dimensional scale of sensing, seizing, and reconfiguring capabilities and found that BDA has positive effects on improving supply chain agility, supply chain adaptability, and performance measures. Bamel and Bamel [25] integrated the resource-based view and dynamic capability view. Applying fuzzy total interpretive structural modeling (TISM), they identified financial support for BDA, people skills for using BDA, IT infrastructure for BDA, and leadership commitment for BDA as enablers of supply chain capability and firm competitiveness.

Dubey et al. [26] examined the impacts of big data analytics capability (BDAC) on supply chain agility (SCA) and competitive advantage. The results demonstrated that BDAC has a positive and significant effect on SCA and competitive advantage and organizational flexibility has a positive and significant moderation effect on the path joining BDAC and SCA. Gu et al. [27] investigated how BDAC is associated with firm performance and demonstrated that a firm's BDAC has not only a direct positive effect on supplier development but also a direct positive effect on its business performance. They also found a full mediation effect of BDAC on the relationship between supplier development and firm performance. Singh and Singh [28] found that BDAC enables firms to effectively develop supply chain risk resilience capacity and partially mediates the impact of IT infrastructure on the firm's risk resilience capacity.

In summary, the above-mentioned studies suggest that $\mathrm{BDAC}$ as dynamics capabilities creates organization value, enhances SC risk resilience/adaptability/agility, and achieves competitive advantage and supplier development.

\subsubsection{Organizational Information Processing Theory (OIPT)}

According to the organizational information processing theory (OIPT), as the task uncertainty increases, an organization can either reduce the need for information or increase information processing capacity to deal with the task uncertainty [40]. Thomas et al. [41] suggested that a higher degree of information use leads to better strategic interpretation, and attention to a wide array of information tends to positively influence the interpretation of strategic issues. BDAC increases the speed of decision making and accelerates the shift of power in the organization [42]. The information processing needs of SCM and the use of BDA for speedy decision making are consistent with tenets of OIPT.

Employing OIPT, Srinivasan and Swink [29] identified demand and supply visibility as a foundational source of analytics capability and organizational flexibility as complementary to analytics capability and demonstrated that analytics capability is more strongly associated with operational performance when supply chain organizations also possess 
organizational flexibility. Yu et al. [30] demonstrated that BDAC has a significant impact on three dimensions of hospital supply chain integration: inter-functional integration, hospital-patient integration, and hospital-supplier integration, and both hospital-patient integration and hospital-supplier integration affect operational flexibility. Using a Delphi method, Roßmann et al. [31] demonstrated that BDA applications enable uncertainty reduction in supply chain operations and enhance supply chain transparency, which facilitates fast decision making and responses to supply chain disruptions.

In summary, BDA contributes to uncertain reduction through the information processing capability, positively affects supply chain integration, and enhances supply chain transparency and operational performance.

\subsubsection{Resource-Based View}

According to a resource-based view (RBV), every firm needs to have a unique set of resources that the firm can leverage to achieve a competitive advantage $[43,44]$. As not all resources are equal in creating a sustainable competitive advantage, many researchers focused on identifying advantage-creating resources. For example, Barney $[43,45]$ suggested that advantage-creating resources must be firm-specific, rare, and difficult to imitate. RBV suggests that firms compete not just in terms of final products, but more fundamentally in terms of the underlying resources, which make production and product diversification possible [46]. It is noted that while the DCV explains how internal technological, organizational, and managerial processes enable firms to generate economic rents in dynamic environments, the RBV is a static view of the firm resources [47].

Gunasekaran et al. [32] conceptualized connectivity and information sharing as resources and big data predictive analytics (BDPA) assimilation as a capability and found that connectivity and information sharing under the partial mediation effect of top management commitment are positively related to acceptance of BDPA and BDPA assimilation is positively related to supply chain performance and organizational performance, respectively. Shafique et al. [33] investigated the impacts of BDPA and radio frequency identification (RFID) technology as resources in pharmaceutical organizations and demonstrated that there is a direct positive effect of BDPA on supply chain performance (SCP), and RFID technology had a partial mediation effect between BDPA and SCP. Fernando et al. [34] investigated the associations among BDA, data security, supply chain innovation capabilities, and service supply chain performances and demonstrated that data security and BDA have a positive effect on the service supply chain innovation capabilities. BDA also has a positive effect on three service supply chain performances: flexibility, reliability, and customer services.

In summary, connectivity and information sharing as resources are positively related to the acceptance of BDPA. The BDPA assimilation process is positively related to supply chain performance and organizational performance. BDA/BDPA also has a positive effect on SCP.

\subsection{Sustainability}

This section focuses on the impacts of BDA on sustainability development and attempts to answer RQ1: What are theoretical views on the value generation mechanisms of BDA in SCM? and RQ2.2: What are the impacts of BDA on sustainability? Seuring and Mueller [48] argued that sustainable supply chain management has received increasing attention from practitioners and suggested environmental, economic, and social sustainability as three dimensions of sustainability. Carter and Rogers [49](p. 368) defined sustainable supply chain management as "the strategic, transparent integration and achievement of an organization's social, environmental, and economic goals in the systemic coordination of key inter-organizational business processes for improving the long-term economic performance of the individual company and its supply chains".

Table 5 summarizes the authors, purpose, theories/views, and constructs/sub-constructs relevant to the theories and views of the 13 selected papers. All 13 papers have confirmed 
the direct or indirect contribution of the BDA/BDAC to the corporate sustainability/circular economy. Theoretical foundations of the selected 13 papers include the dynamic capabilities view (4), stakeholder theory (2), institutional theory (1), resource orchestration theory (1), knowledge-based view (1), and organizational information processing theory (1). The survey was the most frequently used research method (8), followed by an interview (2) and the Delphi method (1). For survey studies, the partial least square structural equations model (PLS-SEM) was the most widely used research method (6), followed by interpretative structural modeling (2).

Table 5. Paper, purpose, theories/views, and constructs/sub-constructs of sustainability.

\begin{tabular}{|c|c|c|c|}
\hline Paper & Purpose & Theories/Views & $\begin{array}{c}\text { Constructs/Sub-Constructs } \\
\text { Relevant to the Theories } \\
\text { and Views }\end{array}$ \\
\hline Dubey et al. [50] & $\begin{array}{l}\text { Investigate the effects of BDPA } \\
\text { on social performance and } \\
\text { environmental performance. }\end{array}$ & Dynamic capabilities & $\begin{array}{c}\text { Technical skills, management } \\
\text { skills, organizational learning, } \\
\text { and data-driven decision } \\
\text { making. }\end{array}$ \\
\hline Bag et al. [51] & $\begin{array}{l}\text { Evaluate the role of BDA } \\
\text { capability in improving } \\
\text { sustainable supply chain } \\
\text { performance. }\end{array}$ & Dynamic capabilities & $\begin{array}{l}\text { Talent capabilities and } \\
\text { management capabilities. }\end{array}$ \\
\hline Singh and El-Kassar [52] & $\begin{array}{l}\text { Investigate the impact of } \\
\text { green human resource } \\
\text { management practices on the } \\
\text { integration of big data } \\
\text { technologies with } \\
\text { processes. }\end{array}$ & Dynamic capabilities & Corporate commitment \\
\hline Stekelorum et al. [53] & $\begin{array}{l}\text { Investigate the impacts of the } \\
\text { supplier's supply chain } \\
\text { ambidexterity and BDAC on } \\
\text { responsible governance and } \\
\text { circular economy practices. }\end{array}$ & Dynamic capabilities & $\begin{array}{l}\text { Supply chain ambidexterity } \\
\text { and BDAC. }\end{array}$ \\
\hline Wang et al. [54] & $\begin{array}{l}\text { Explore the relationship } \\
\text { between corporate social } \\
\text { responsibility (CSR), green } \\
\text { SCM, and firm performance in } \\
\text { the context of BDAC. }\end{array}$ & Stakeholder theory & $\begin{array}{l}\text { Internal CSR and external } \\
\text { CSR. }\end{array}$ \\
\hline Gupta et al. [55] & $\begin{array}{c}\text { Investigate the impact of BDA } \\
\text { on the adoption of the circular } \\
\text { economy paradigm. }\end{array}$ & Stakeholder theory & $\begin{array}{l}\text { Mutual support, coordination, } \\
\text { and holistic information } \\
\text { processing and sharing. }\end{array}$ \\
\hline Bag et al. [56] & $\begin{array}{l}\text { Examine the impacts of } \\
\text { institutional forces on tangible } \\
\text { resources and workforce skills } \\
\text { in the development of } \\
\text { BDA-artificial intelligence and } \\
\text { on sustainable manufacturing } \\
\text { practices and circular } \\
\text { economy capabilities. }\end{array}$ & $\begin{array}{l}\text { Institutional theory/resource } \\
\text {-based view }\end{array}$ & $\begin{array}{l}\text { Institutional pressures (e.g., } \\
\text { coercive pressures, normative } \\
\text { pressures, and mimetic } \\
\text { pressures) and resources } \\
\text { (tangible resources and } \\
\text { workforce skills). }\end{array}$ \\
\hline AlNuaimi et al. [57] & $\begin{array}{l}\text { Investigate the effects of } \\
\text { BDAC on e-procurement and } \\
\text { environmental performance. }\end{array}$ & $\begin{array}{l}\text { Resource orchestration } \\
\text { theory }\end{array}$ & $\begin{array}{c}\text { E-procurement, } \\
\text { technological capabilities } \\
\text { (data availability and } \\
\text { technological infrastructure), } \\
\text { and human capabilities } \\
\text { (managerial experience and } \\
\text { employee skills). }\end{array}$ \\
\hline
\end{tabular}


Table 5. Cont.

\begin{tabular}{|c|c|c|c|}
\hline Paper & Purpose & Theories/Views & $\begin{array}{c}\text { Constructs/Sub-Constructs } \\
\text { Relevant to the Theories } \\
\text { and Views }\end{array}$ \\
\hline Mani et al. [58] & $\begin{array}{l}\text { Explore the application of } \\
\text { BDA in mitigating supply } \\
\text { chain social risk. }\end{array}$ & Knowledge-based View & BDA as a knowledge base \\
\hline Benzidia et al. [59] & $\begin{array}{l}\text { Evaluate the benefits of } \\
\text { BDA-artificial intelligence in } \\
\text { the supply chain integration } \\
\text { process and its impact on } \\
\text { environmental performance. }\end{array}$ & $\begin{array}{l}\text { Organizational information } \\
\text { processing theory }\end{array}$ & $\begin{array}{c}\text { BDA-AI technology, } \\
\text { green digital learning } \\
\text { orientation, environmental } \\
\text { process integration, and green } \\
\text { supply chain collaboration. }\end{array}$ \\
\hline Raut et al. [60] & $\begin{array}{l}\text { Investigate whether BDA acts } \\
\text { as a mediator to influence the } \\
\text { business performance of a } \\
\text { sustainable supply chain } \\
\text { when considering lean, agile, } \\
\text { resilient, and green aspects. }\end{array}$ & No specific theory/view & $\begin{array}{l}\text { Organizational practices, lean } \\
\text { management practices, SCM } \\
\text { practices, social practices in } \\
\text { supply chain, environmental } \\
\text { practices, financial practices, } \\
\text { and total quality management. }\end{array}$ \\
\hline Kazancoglu et al. [61] & $\begin{array}{l}\text { Evaluate drivers of BDA in the } \\
\text { context of food supply chains } \\
\text { for transition to a circular } \\
\text { economy and sustainable } \\
\text { operations management. }\end{array}$ & No specific theory/view & $\begin{array}{c}\text { Drivers of BDA: } \\
\text { governmental incentives, } \\
\text { information management and } \\
\text { technology, management team } \\
\text { capability, collaborations } \\
\text { between supply chain } \\
\text { partners, } \\
\text { supply chain visibility, } \\
\text { talent management, and } \\
\text { data-driven innovation. }\end{array}$ \\
\hline Bag et al. [62] & $\begin{array}{l}\text { Identify barriers to BDA in } \\
\text { sustainable humanitarian } \\
\text { SCM and understand the } \\
\text { interrelationships among the } \\
\text { barriers. }\end{array}$ & No specific theory/view & $\begin{array}{c}\text { Fifteen barriers to BDA in } \\
\text { sustainable humanitarian } \\
\text { SCM }\end{array}$ \\
\hline
\end{tabular}

\subsubsection{Dynamic Capabilities View}

Recently, there has been growing attention and a call for further research on the DCV in the circular economy and sustainability (e.g., [63]). Several studies on the BDA in SCM applied the DCV to understanding the relationship between BDA and sustainable supply chain performance. For example, Dubey et al. [50] conceptualized BDPA as a higher-order reflective construct that reflects technical skills, management skills, organizational learning, and data-driven decision-making as sources of dynamic capabilities. They found that the dynamic capabilities of BDPA have a significant impact on social performance and environmental performance, but did not find evidence of moderating roles of flexible orientation and control orientation between BDPA and social performance and environmental performance. Bag et al. [51] conceptualized BDA management capabilities and talent capabilities as dynamic capabilities and demonstrated that BDA management capabilities positively affect innovative green product development and BDA talent capabilities affect employee development.

Singh and El-Kassar [52] suggested that the support and commitment of top management play a critical role in creating unique information processing capabilities of BDA and found that corporate commitment influences big data assimilation through acceptance and routinization routes, which, in turn, enhances firms' sustainable performance. Stekelorum et al. [53] found that a focal firm's supplier development positively influences the supplier's 
BDAC through the supplier's supply chain ambidexterity and that the supplier's BDAC significantly and positively influences the focal firm's circular economy practices.

\subsubsection{Stakeholder Theory}

Stakeholder theory explains the firm's relationships with other stakeholders, such as customers, suppliers, creditors, and local communities [64,65]. Building on stakeholder theory, Hasan et al. [66] argued that by forging strong relationships with key stakeholders through participation in social issues, a firm can efficiently utilize the assets, obtain competitive advantages over rivals, and create shareholder value.

Based on the stakeholder theory, Wang et al. [54] demonstrated that both internal CSR (management practice towards employees) and external CSR (management practice towards external stakeholders) have a positive effect on green supply chain management, green supply chain management has a positive effect on firm performance, and BDAC is moderating on the relationship between external CSR and global supply chain management. Gupta et al. [55] proposed a stakeholder perspective on the circular economy and suggested that mutual support and coordination driven by a stakeholder perspective coupled with holistic information processing and sharing by BDA can effectively create a basis for achieving economic, ecological, and social benefits.

\subsubsection{Other Theories/Views}

Applying institutional theory and a resource-based view, Bag et al. [56] demonstrated that the paths "BDA-artificial intelligence and sustainable manufacturing" and "BDA-AI and circular economy capabilities" are significant. Building on resource orchestration theory, AlNuaimi et al. [57] demonstrated that the perceived implementation of e-procurement (EP) does not have a significant effect on environmental performance (ENP), but BDAC fully mediates between EP and ENP. Building on a knowledge-based view, Mani et al. [58] demonstrated how companies can predict various social problems using BDA and mitigate environmental, economic, and social risks. Applying organizational information processing theory, Benzidia et al. [59] demonstrated that the use of BDA-artificial intelligence (AI) has a significant effect on environmental process integration and green supply chain collaboration and both environmental process integration and green supply chain collaboration have a significant impact on environmental performance.

\subsection{Implementation Challenges}

This section focuses on the implementation challenges and attempts to answer RQ1: What are theoretical views on the value generation mechanisms of BDA in SCM? Table 6 summarizes the authors, purpose, theories/views, and constructs/sub-constructs relevant to the theories and views of the six selected papers. Three papers investigated implementation challenges and risks in the context of manufacturing firms. Papers in this category focus on the drivers, risks, and challenges of adoption and implementation. Most studies do not use particular theories. To identify and analyze the implementation challenges, researchers apply Delphi methods (4) and surveys (2). While a number of the sustainability and performance studies built on dynamic capabilities view and organizational information processing theory, studies on implementation challenges utilized a resource-based view, diffusion of innovation theory (DOI), a technology-organization-environment (TOE) framework, and others. It is interesting to note that, unlike the sustainability and performance studies that preferred the survey method, studies on implementation challenges used the Delphi method the most frequently. 
Table 6. Paper, purpose, theories/views, and constructs/sub-constructs of BDA implementation challenges.

\begin{tabular}{|c|c|c|c|}
\hline Paper & Purpose & Theories/Views & $\begin{array}{c}\text { Constructs/Sub-Constructs } \\
\text { Relevant to the Theories } \\
\text { and Views }\end{array}$ \\
\hline Lai et al. [67] & $\begin{array}{l}\text { Identify factors affecting firms' } \\
\text { intention to adopt BDA. }\end{array}$ & $\begin{array}{l}\text { Diffusion of innovation } \\
\text { theory (DOI) and technology- } \\
\text { organization-environment } \\
\text { (TOE) framework. }\end{array}$ & $\begin{array}{l}\text { Perceived benefits, technology } \\
\text { complexity, data quality, IT } \\
\text { infrastructure/capabilities, } \\
\text { financial readiness, and } \\
\text { top management support }\end{array}$ \\
\hline Khan [68] & $\begin{array}{l}\text { Propose a framework to } \\
\text { address challenges in } \\
\text { employing BDA for service } \\
\text { supply chains. }\end{array}$ & $\begin{array}{l}\text { The stakeholder theory, } \\
\text { resource-based view, } \\
\text { transaction cost economics, } \\
\text { and systems theory. }\end{array}$ & $\begin{array}{l}\text { The technical, cultural, } \\
\text { ethical, operational, tactical, } \\
\text { procedural, functional, and } \\
\text { organizational challenge. }\end{array}$ \\
\hline Kusi-Sarpong et al. [69] & $\begin{array}{l}\text { Propose a framework of risks } \\
\text { to implementing BDA within } \\
\text { sustainable supply chains. }\end{array}$ & $\begin{array}{l}\text { TOE framework and human- } \\
\text { organizational-technological } \\
\text { (HOT) framework. }\end{array}$ & $\begin{array}{l}\text { Technological risks. } \\
\text { Institutional risks, } \\
\text { human risks, and } \\
\text { organizational risks }\end{array}$ \\
\hline Kache and Seuring [70] & $\begin{array}{l}\text { Identify the potential } \\
\text { challenges and opportunities } \\
\text { related to BDA at a corporate } \\
\text { and supply chain level. }\end{array}$ & No specific theory & $\begin{array}{l}\text { Opportunity constructs: } \\
\text { "supply chain visibility and } \\
\text { transparency" and } \\
\text { "operations efficiency and } \\
\text { maintenance" } \\
\text { Challenge constructs: "IT } \\
\text { capabilities and infrastructure" } \\
\text { and "information and cyber } \\
\text { security" } \\
\text { Opportunity and challenge } \\
\text { construct: "integration and } \\
\text { collaboration". }\end{array}$ \\
\hline Moktadir et al. [71] & $\begin{array}{l}\text { Identify the critical barriers to } \\
\text { the adoption of BDA. }\end{array}$ & No specific theory & $\begin{array}{c}\text { Five most important } \\
\text { sub-barriers among } 15 \\
\text { identified sub-barriers: (1) } \\
\text { lack of infrastructural facility, } \\
\text { (2) complexity of data } \\
\text { integration, (3) data privacy, } \\
\text { (4) lack of availability of BDA } \\
\text { tools, and (5) high cost of } \\
\text { investment. }\end{array}$ \\
\hline Raut et al. [72] & $\begin{array}{c}\text { Identify the obstacles to BDA } \\
\text { implementation in the context } \\
\text { of the Indian manufacturing } \\
\text { supply chain. }\end{array}$ & No specific theory & $\begin{array}{l}\text { Top } 4 \text { most critical barriers: } \\
\text { "lack of top management } \\
\text { support", "lack of financial } \\
\text { support", "lack of skill", and } \\
\text { "lack of techniques or } \\
\text { procedures". }\end{array}$ \\
\hline
\end{tabular}

Employing diffusion of innovation (DOI) theory and the technology-organizationenvironment (TOE) framework, Lai et al. [67] found that perceived benefits and top management support can significantly influence the adoption intention of BDA, and environmental factors and supply chain connectivity can significantly moderate the direct relationships between driving factors and the adoption intention. Khan [68] employed multiple theories/views (i.e., stakeholder theory, resource-based view, transaction cost economics, and systems theory) to explore challenges in adopting BDA and demonstrated that technical, cultural, ethical, operational, tactical, procedural, functional, and organizational factors have a significant impact on BDA adoption and the highest and lowest impacts come from ethical and technical factors.

Several papers employed the Delphi method to identify the implementation challenges of BDA in SCM. Kusi-Sarpong et al. [69] employed a Delphi method and developed the 
integrated TOE and human-organizational-technological (HOT) framework to classify the risk to implementing BDA for a sustainable supply chain. Kache and Seuring [70] applied a Delphi method with a panel of 15 big data analytics experts from the industry. After the three rounds of the Delphi study, the experts found 43 opportunities/challenges and categorized them into five overarching opportunities/challenges constructs.

Moktadir et al. [71] applied a Delphi-based analytic hierarchy process (AHP) approach to identify barriers to the use of BDA and categorized 15 sub-barriers into four main barriers: technology-related barriers, expertise- and investment-related barriers, data-related barriers, and organizational barriers. Among the main barriers, data-related barriers are most important followed by technology-related barriers. Raut et al. [72] used interpretive structural modeling (ISM) to identify barriers and conducted a fuzzy-MICMAC analysis to study the interrelationships between identified barriers. Among 12 barriers identified, the top four most critical barriers against BDA adoption are "lack of top management support", "lack of financial support", "lack of skill", and "lack of techniques or procedures".

\section{Technical Perspectives on BDA in SCM}

This section attempts to answer RQ3: What types of BDA applications, architecture, and infrastructure have been used for different supply chain functions? and RQ4: What are the technical performances of BDA techniques and algorithms? The literature review demonstrated that numerous technologies/infrastructures have been developed and evaluated for BDA in SCM. Based on the thematic analysis of the selected papers, the technical perspectives are broadly categorized into (1) applications of BDA and (2) architecture/infrastructure.

\subsection{Applications of $B D A$}

Table 7 summarizes the authors, purpose, SCOR processes, types of BDA, and techniques/algorithms of the 17 selected papers. These papers focus on descriptive analytics (three papers), predictive analytics (12 papers), and prescriptive analytics (two papers).

Table 7. Paper, purpose, SCOR processes, types of BDA, and techniques/algorithms of applications.

\begin{tabular}{|c|c|c|c|c|}
\hline Paper & Purpose & SCOR Process & Types of Analytics & $\begin{array}{l}\text { Techniques/ } \\
\text { Algorithms }\end{array}$ \\
\hline Brandtner et al. [73] & $\begin{array}{l}\text { Investigate the impact } \\
\text { of COVID-19 on the } \\
\text { customer end of retail } \\
\text { supply chains in } \\
\text { physical grocery } \\
\text { shopping in Austria. }\end{array}$ & Deliver & Descriptive analytics & $\begin{array}{l}\text { Descriptive statistics } \\
\text { and categorization } \\
\text { techniques with } \\
\text { text mining. }\end{array}$ \\
\hline Egilmez et al. [74] & $\begin{array}{c}\text { Develop an analytical } \\
\text { sustainability } \\
\text { assessment framework } \\
\text { to assess the carbon } \\
\text { footprint of US } \\
\text { economic supply } \\
\text { chains. }\end{array}$ & $\begin{array}{c}\text { Source, make, and } \\
\text { deliver }\end{array}$ & Descriptive analytics & $\begin{array}{l}\text { Data visualization, I-O } \\
\text { analysis and lifecycle } \\
\text { assessment (LCA), and } \\
\text { statistical approaches. }\end{array}$ \\
\hline Chae [75] & $\begin{array}{l}\text { Explore the use of } \\
\text { Twitter for supply } \\
\text { chain practices. }\end{array}$ & All processes of SCOR & Descriptive analytics & $\begin{array}{c}\text { Text analysis, sentiment } \\
\text { analysis, descriptive } \\
\text { statistics, network } \\
\text { analysis, and } \\
\text { visualization. }\end{array}$ \\
\hline
\end{tabular}


Table 7. Cont.

\begin{tabular}{|c|c|c|c|c|}
\hline Paper & Purpose & SCOR Process & Types of Analytics & $\begin{array}{l}\text { Techniques/ } \\
\text { Algorithms }\end{array}$ \\
\hline Keller et al. [76] & $\begin{array}{l}\text { Investigate the use of } \\
\text { data } \\
\text { mining techniques for } \\
\text { filtering and } \\
\text { aggregating raw RFID } \\
\text { data. }\end{array}$ & Deliver & Predictive analytics & $\begin{array}{l}\text { Logistic regression, } \\
\text { decision trees, artificial } \\
\text { neural networks, and } \\
\text { rule-based classifier. }\end{array}$ \\
\hline Kinra et al. [77] & $\begin{array}{l}\text { Explore the potential } \\
\text { for the development of } \\
\text { an automated textual } \\
\text { BDA approach that can } \\
\text { provide country } \\
\text { logistics performance } \\
\text { assessments. }\end{array}$ & Deliver & Predictive analytics & $\begin{array}{l}\text { A mix of supervised } \\
\text { keyword analysis, } \\
\text { unsupervised word } \\
\text { frequency analysis, and } \\
\text { collocation analysis, } \\
\text { and } \\
\text { naive Bayes classifier } \\
\text { for text classification. }\end{array}$ \\
\hline Wang et al. [78] & $\begin{array}{l}\text { Develop an online } \\
\text { supply chain financial } \\
\text { credit risk assessment } \\
\text { index system for a } \\
\text { commercial bank to } \\
\text { evaluate supply chain } \\
\text { financial risk. }\end{array}$ & Enable & Predictive analytics & $\begin{array}{c}\text { Nonlinear least-squares } \\
\text { support vector } \\
\text { machines (LS-SVM) } \\
\text { model and logistic } \\
\text { regression model. }\end{array}$ \\
\hline Yeboah-Ofori et al. [79] & $\begin{array}{l}\text { Integrate cyber threat } \\
\text { intelligence and } \\
\text { machine learning } \\
\text { techniques to predict } \\
\text { cyberattack patterns on } \\
\text { cyber supply chain } \\
\text { systems. }\end{array}$ & Enable & Predictive analytics & $\begin{array}{l}\text { Logistic regression, } \\
\text { support vector } \\
\text { machine, random } \\
\text { forest, and decision } \\
\text { tree. }\end{array}$ \\
\hline Scheidt and Chung [80] & $\begin{array}{l}\text { Evaluated the efficacy } \\
\text { of a customer service } \\
\text { quality } \\
\text { improvement program } \\
\text { that used speech } \\
\text { analytics tools at a call } \\
\text { center. }\end{array}$ & Enable & Prescriptive analytics & $\begin{array}{l}\text { Statistical analysis } \\
\text { and speech recognition. }\end{array}$ \\
\hline Leung et al. [81] & $\begin{array}{l}\text { Develop predictive } \\
\text { analytics for forecasting } \\
\text { near-real-time } \\
\text { e-commerce order } \\
\text { arrivals at distribution } \\
\text { centers. }\end{array}$ & Deliver & Predictive analytics & $\begin{array}{c}\text { An adaptive } \\
\text { neuro-fuzzy inference } \\
\text { system. }\end{array}$ \\
\hline Iftikhar and Khan [82] & $\begin{array}{l}\text { Improve demand } \\
\text { forecasting in a supply } \\
\text { chain using social } \\
\text { media data from } \\
\text { Twitter and Facebook. }\end{array}$ & Plan & $\begin{array}{l}\text { Predictive analytics; } \\
\text { descriptive analytics }\end{array}$ & $\begin{array}{l}\text { Word analysis, topic } \\
\text { modeling using } \\
\text { Latent Dirichlet } \\
\text { Allocation, Naïve Bayes } \\
\text { (NB) algorithm, and } \\
\text { support vector machine } \\
\text { (SVM) for sentiment } \\
\text { analysis. }\end{array}$ \\
\hline
\end{tabular}


Table 7. Cont.

\begin{tabular}{|c|c|c|c|c|}
\hline Paper & Purpose & SCOR Process & Types of Analytics & $\begin{array}{l}\text { Techniques/ } \\
\text { Algorithms }\end{array}$ \\
\hline Singh et al. [83] & $\begin{array}{l}\text { Propose BDA for social } \\
\text { media data for the } \\
\text { identification of SCM } \\
\text { issues in food } \\
\text { industries. }\end{array}$ & Enable & $\begin{array}{l}\text { Predictive analytics; } \\
\text { descriptive analytics }\end{array}$ & $\begin{array}{l}\text { Sentiment analysis } \\
\text { based on SVM, word } \\
\text { and hashtag analysis, } \\
\text { and hierarchical } \\
\text { clustering with } \\
p \text {-values using } \\
\text { multiscale bootstrap } \\
\text { resampling. }\end{array}$ \\
\hline Sathyan et al. [84] & $\begin{array}{c}\text { Analyze vehicle } \\
\text { attributes and develop } \\
\text { a model to forecast the } \\
\text { demand. }\end{array}$ & Plan & $\begin{array}{l}\text { Predictive analytics; } \\
\text { descriptive analytics }\end{array}$ & $\begin{array}{c}\text { Sentiment analysis and } \\
\text { artificial neural } \\
\text { network. }\end{array}$ \\
\hline Chang et al. [85] & $\begin{array}{l}\text { Develop a predictive } \\
\text { model for the efficient } \\
\text { detection of } \\
\text { environmental } \\
\text { violators. }\end{array}$ & Enable & $\begin{array}{l}\text { Predictive analytics; } \\
\text { descriptive analytics }\end{array}$ & $\begin{array}{c}\text { Machine learning } \\
\text { (clustering } \\
\text { algorithm-based), } \\
\text { positive and unlabeled } \\
\text { learning, } \\
\text { long short-term } \\
\text { memory, logistic } \\
\text { regression, AdaBoost, } \\
\text { etc. for comparison } \\
\text { purpose. }\end{array}$ \\
\hline Wang et al. [86] & $\begin{array}{l}\text { Explore BDA tools for } \\
\text { B2B e-commerce } \\
\text { customer } \\
\text { segmentation. }\end{array}$ & Plan & $\begin{array}{l}\text { Predictive analytics; } \\
\text { descriptive analytics }\end{array}$ & $\begin{array}{c}\text { A hybrid model } \\
\text { combining recency, } \\
\text { frequency, and } \\
\text { monetary value (RFM) } \\
\text { model, k-means } \\
\text { clustering, Naïve Bayes } \\
\text { algorithm, and linked } \\
\text { Bloom filters. }\end{array}$ \\
\hline Lau et al. [87] & $\begin{array}{l}\text { Design a BDA } \\
\text { methodology for } \\
\text { sentiment analysis to } \\
\text { improve sales } \\
\text { forecasting. }\end{array}$ & Plan & $\begin{array}{l}\text { Predictive analytics; } \\
\text { descriptive analytics }\end{array}$ & $\begin{array}{l}\text { Parallel aspect-oriented } \\
\text { sentiment analysis, } \\
\text { topic model; } \\
\text { sentiment-based sales } \\
\text { forecasting linear } \\
\text { regression, } \\
\text { support vector } \\
\text { regression, and the } \\
\text { parallel co-evolutionary } \\
\text { extreme learning } \\
\text { machine. }\end{array}$ \\
\hline Lee [88] & $\begin{array}{l}\text { Predict a customer's } \\
\text { purchase time and ship } \\
\text { the product to the } \\
\text { nearest distribution } \\
\text { centers before the } \\
\text { customer places the } \\
\text { orders online. }\end{array}$ & Deliver & $\begin{array}{l}\text { Prescriptive analytics; } \\
\text { predictive analytics }\end{array}$ & $\begin{array}{l}\text { Cluster-based } \\
\text { association rule mining } \\
\text { and genetic algorithm. }\end{array}$ \\
\hline Zhong et al. [89] & $\begin{array}{l}\text { Explore the use of BDA } \\
\text { to analyze RFID } \\
\text { logistics data and } \\
\text { understand behaviors } \\
\text { of smart manufacturing } \\
\text { objects. }\end{array}$ & Make & $\begin{array}{l}\text { Prescriptive analytics; } \\
\text { predictive analytics }\end{array}$ & $\begin{array}{l}\text { Descriptive statistics, } \\
\text { and data visualization } \\
\text { for trend analysis and } \\
\text { key performance. }\end{array}$ \\
\hline
\end{tabular}




\subsubsection{Descriptive Analytics}

Recent pandemic-induced global supply chain disruptions highlight challenges faced by supply chain participants and demonstrated the importance of analytics-driven SCM. Brandtner et al. [73] investigated the impact of COVID-19 on grocery shopping customers at retail supply chains in Austria through the analysis of consumer data and sentiments available on the websites utilizing descriptive statistics and text mining to analyze unstructured textual data to identify significant patterns and correlations in the data [90]. Their analysis identified factors that shaped consumer sentiments, such as store layout and facilities, product availability and waiting time. Egilmez et al. [74] presented a procedure that employs input-output (I-O) lifecycle assessment (LCA), data visualization, and statistical approaches to trace the detailed greenhouse gas emissions within the supply chain of the US manufacturing industry. Chae [75] proposed an analytical framework of Twitter analytics for the analysis of supply chain tweets and shed insights into the potential role of Twitter for supply chain practice and research.

\subsubsection{Predictive Analytics}

Keller et al. [76] examined the use of BDA for RFID data filtering and real-time detection of process events in SCM. They evaluated the logistic regression, decision tree, artificial neural network, and rule-based classifier and found that the rule-based classifier with an iterative training algorithm for the generation of decision rules achieved the best overall classification performance. Kinra et al. [77] developed an automated textual BDA approach that can provide country logistics performance assessments of a text corpus from the periodical, Global Perspectives. They applied a mix of supervised keyword analysis, unsupervised word frequency and collocation analysis, and a naive Bayes classifier for text classification and found the performance of the classifier for the logistics performance categories was much better than the baseline accuracy. Wang et al. [78] investigated the use of BDA for the online supply chain financial credit risk assessment at a commercial bank and found that the prediction accuracy of the nonlinear least-squares support vector machines (LS-SVM) model was higher than that of the logistic regression model.

Yeboah-Ofori et al. [79] integrated cyber threat intelligence and machine learning techniques to predict cyberattack patterns on cyber supply chain systems and found that overall, random forest and logistic regression performed better than support vector machine, random forest, and decision tree. Scheidt and Chung [80] analyzed speech analytics to the Customer Service Quality Improvement Program (CSQIP) for call center operations and demonstrated that speech recognition and statistical methods helped CSQIP significantly improve the quality of customer service at call centers. Leung et al. [81] proposed an adaptive neuro-fuzzy inference system (ANFIS) for forecasting near-real-time e-commerce order arrivals at distribution centers and demonstrated that the proposed ANFIS-based approach gives a $200 \%$ better prediction performance than the autoregressive integrated moving average (ARIMA) model in forecasting order arrivals.

Other studies combined descriptive analytics and predictive analytics. Iftikhar and Khan [82] developed descriptive and predictive analytics for sentiment analysis and demand forecasting and demonstrated that the forecasting accuracy of their proposed emotionenhanced model was significantly improved on the forecasting accuracy of the original Bass Model. Singh et al. [83] used social media data analytics, support vector machine (SVM), and hierarchical clustering with multiscale bootstrap resampling to identify root causes affecting consumer satisfaction in various segments in the food industry supply chains and demonstrated that the performance of the SVM is better than that of the Naive Bayes (NB) classifier in terms of sentiment classification.

Sathyan et al. [84] developed a predictive model to forecast the demand using the sentiment analysis of product review and an artificial neural network and demonstrated that the proposed approach achieved an accuracy of 95.5\%. Chang et al. [85] developed machine learning-based prediction models to efficiently catch environmental violators based on the analysis of waste gas data from the continuous emission monitoring system 
(CEMS) and a publicly available violation and punishment dataset (VPD). The results demonstrated that the proposed machine learning-based prediction models demonstrated robustness and good performance in detecting violators, due to their simplicity, efficiency, and detection accuracy.

Wang et al. [86] developed a hybrid BDA model combining recency, frequency, and monetary value (RFM) model, K-means clustering, Naïve Bayes algorithm, and linked Bloom filters for B2B e-commerce customer segmentation. They applied the proposed BDA model to a fast-moving consumer goods (FMCG) company in Indonesia to address diverse ordering or pricing strategies to the customers. Lau et al. [87] proposed parallel aspectoriented sentiment analysis and the parallel co-evolutionary extreme learning machine (PELM) based on a hidden-layer feed-forward neural network to mine context-sensitive sentiments from product comments to enhance sales forecasting performance. Their experiments demonstrated that the PELM predictive model empowered by the sentiment feature outperforms the best baseline model by $12.2 \%$ in terms of root mean squared error (RMSE).

\subsubsection{Prescriptive Analytics}

In our literature review, two papers were identified as focused on prescriptive analytics with predictive analytics as a complementary tool. Lee [88] proposed an optimization model for determining the allocation of products to different distribution centers based on multiple factors, including transportation cost, traveling time, and the confidence of the prediction results. Cluster-based association rule mining is applied to analyze the big data and discover hidden customer purchase patterns and predict future purchases. With the obtained rules, a genetic algorithm (GA) was used to generate a nearly optimal solution for anticipatory shipping. Zhong et al. [89] explored the use of BDA to analyze behaviors of smart manufacturing objects. They modeled RFID data for intelligent shop floors equipped with RFID systems and wireless networks and used BDA to calculate a set of performance indicators. The discovered logistics knowledge and logistics rules were useful for various users to make logistics decisions.

\subsubsection{BDA for SCOR Processes}

Supply Chain Council developed the Supply Chain Operations Reference (SCOR) model in 1996. According to Supply Chain Operations Reference Model SCOR Version 12.0 [91], the SCOR model focuses on the operational process of supply chains and includes macro-level SCOR processes: (1) plan, (2) source, (3) make, (4) deliver, (5) return, and (6) enable. Zhou et al. [92] demonstrated that the relationships among four original supply chain processes in the SCOR model are generally supported. SCOR models have been widely used in supply chain practices and research (e.g., [93-96]). Among the six functions of the SCOR model, "deliver" (five papers) and "enable" (five papers) are the most popular functions supported by BDA followed by "plan" (four papers) and "make" (one paper).

\subsection{Architecture/Infrastructure for BDA}

The literature review showed many architectures/infrastructures have been developed and implemented for BDA in SCM. Among eight selected papers, three papers focused on descriptive analytics and, five papers focused on prescriptive analytics. Table 8 summarizes the authors, purpose, SCOR processes, types of BDA, and features of the eight selected papers. It is noted that seven studies on the development of architecture and infrastructure focused on the "enable" function of the SCOR model. Only one study focused on the "deliver" function of the SCOR model. In the following, the architectures/infrastructures are discussed. 
Table 8. Paper, purpose, SCOR processes, types of BDA, and features of architecture/infrastructure.

\begin{tabular}{|c|c|c|c|c|}
\hline Paper & Purpose & SCOR Process & Types of Analytics & Features \\
\hline Venkatesh et al. [97] & $\begin{array}{l}\text { Develop a system } \\
\text { architecture that } \\
\text { integrates blockchain, } \\
\text { internet-of-things (IoT), } \\
\text { and BDA to allow } \\
\text { sellers to monitor their } \\
\text { supply chain social } \\
\text { sustainability. }\end{array}$ & Enable & Descriptive analytics & $\begin{array}{l}\text { Five layers of system } \\
\text { architecture: smart } \\
\text { objects, communication } \\
\text { channels, data analysis, } \\
\text { blockchain network, } \\
\text { and applications. }\end{array}$ \\
\hline Molka-Danielsen et al. [98] & $\begin{array}{l}\text { Present a case study on } \\
\text { air quality monitoring } \\
\text { at two workshops of an } \\
\text { on-shore logistics base. }\end{array}$ & Enable & Descriptive analytics & $\begin{array}{l}\text { Smart closed-loop } \\
\text { system for work } \\
\text { space safety data } \\
\text { analytics integrated } \\
\text { with wireless sensor } \\
\text { network (WSN) } \\
\text { technologies. }\end{array}$ \\
\hline Fernández-Caramés et al. [99] & $\begin{array}{l}\text { Present an unmanned } \\
\text { aerial vehicle } \\
\text { (UAV)-based system } \\
\text { aimed at automating } \\
\text { inventory management } \\
\text { and keeping the } \\
\text { traceability of } \\
\text { industrial items } \\
\text { attached to } \\
\text { radio-frequency } \\
\text { identification (RFID) } \\
\text { tags. }\end{array}$ & Deliver & Descriptive analytics & $\begin{array}{c}\text { A UAV with } \\
\text { a single-board } \\
\text { computer (SBC) and a } \\
\text { tag reader, wireless } \\
\text { communications } \\
\text { interface to a ground } \\
\text { station, internal } \\
\text { software modules to } \\
\text { send the collected } \\
\text { information to a } \\
\text { decentralized remote } \\
\text { storage network or a } \\
\text { blockchain. }\end{array}$ \\
\hline Giannakis and Louis [100] & $\begin{array}{c}\text { Develop a } \\
\text { multi-agent-based } \\
\text { supply chain } \\
\text { management system } \\
\text { that incorporates BDA } \\
\text { that can exert } \\
\text { autonomous corrective } \\
\text { control actions. }\end{array}$ & Enable & $\begin{array}{c}\text { Prescriptive analytics; } \\
\text { descriptive analytics; } \\
\text { predictive analytics }\end{array}$ & $\begin{array}{c}\text { 5-layered architecture, } \\
\text { a multitude of software } \\
\text { agents responsible for } \\
\text { production processes, a } \\
\text { module of agents } \\
\text { responsible for supply } \\
\text { chain } \\
\text { event management, } \\
\text { and a module of agents } \\
\text { responsible for } \\
\text { disruption risk } \\
\text { management } \\
\text { processes. }\end{array}$ \\
\hline Ivanov and Dolgui [101] & $\begin{array}{l}\text { Explore the conditions } \\
\text { surrounding the design } \\
\text { and } \\
\text { implementation of the } \\
\text { digital twins for } \\
\text { managing disruption } \\
\text { risks in supply chains. }\end{array}$ & Enable & $\begin{array}{c}\text { Prescriptive analytics; } \\
\text { descriptive analytics; } \\
\text { predictive analytics }\end{array}$ & $\begin{array}{l}\text { Disruption data as } \\
\text { inputs, reactive } \\
\text { recovery plan, and } \\
\text { proactive resilient } \\
\text { supply chain design. }\end{array}$ \\
\hline
\end{tabular}


Table 8. Cont.

\begin{tabular}{|c|c|c|c|c|}
\hline Paper & Purpose & SCOR Process & Types of Analytics & Features \\
\hline Zhan and Tan [102] & $\begin{array}{l}\text { Propose an integrated } \\
\text { infrastructure for } \\
\text { breaking down the } \\
\text { information silos. }\end{array}$ & Enable & $\begin{array}{c}\text { Prescriptive analytics; } \\
\text { descriptive analytics; } \\
\text { predictive analytics }\end{array}$ & $\begin{array}{c}\text { Five main stages: } \\
\text { - Stage one: data } \\
\text { capture and } \\
\text { management } \\
\text { - Stage two: data } \\
\text { cleaning and } \\
\text { integration } \\
\text { - Stage three: data } \\
\text { analytics } \\
\text { - Stage four: } \\
\text { competence set } \\
\text { analysis-deduction } \\
\text { graph } \\
\text { • Stage five: } \\
\text { information } \\
\text { interpretation and } \\
\text { decision making. }\end{array}$ \\
\hline Kim et al. [103] & $\begin{array}{l}\text { Introduce a PRocess } \\
\text { ANAlytics System } \\
\text { (PRANAS) which was } \\
\text { developed to evaluate } \\
\text { the operational } \\
\text { performance of supply } \\
\text { chain operations. }\end{array}$ & Enable & $\begin{array}{l}\text { Prescriptive analytics; } \\
\text { descriptive analytics; } \\
\text { predictive analytics }\end{array}$ & $\begin{array}{l}\text { Process warehouse and } \\
\text { process cube. }\end{array}$ \\
\hline Er Kara et al. [104] & $\begin{array}{c}\text { Develop a data } \\
\text { mining-based } \\
\text { framework for the } \\
\text { identification, } \\
\text { assessment, and } \\
\text { mitigation of different } \\
\text { types of risks in supply } \\
\text { chains. }\end{array}$ & Enable & Prescriptive analytics & $\begin{array}{l}\text { Risk data warehouse } \\
\text { and data mining } \\
\text { module. }\end{array}$ \\
\hline
\end{tabular}

\subsubsection{Architecture/Infrastructure for Descriptive Analytics}

Venkatesh et al. [97] developed a blockchain-based supply chain social sustainability management (BSCSSM) system that integrates the use of blockchain, IoT, and big data analytics for social sustainability traceability. Four application areas of BSCSSM include production and logistics traceability, supply chain transparency, labor and human rights, and workplace health and safety. Molka-Danielsen et al. [98] proposed a system analytics approach to managing big data in monitoring air quality at an industrial workplace. They presented a case study involving analysis of air quality big data that are collected with wireless sensor networks (WSN) technologies and demonstrated the applicability of the analytics for decision making in the shipping industry. Fernández-Caramés et al. [99] described an RFID-based drone system with a blockchain and a decentralized storage network for performing inventory management tasks and demonstrated that the system helps a real warehouse collect inventory data remarkably faster than a human operator.

\subsubsection{Architecture/Infrastructure for Prescriptive Analytics}

Simulation and optimization techniques are widely used for prescriptive analytics. Giannakis and Louis [100] developed the architecture of a multi-agent-based supply chain system and demonstrated how the proposed systems can promote supply chain agility. Based on the hypothesized scenarios, they showed its potential advantage over conventional IT tools for effective SCM and the autonomous decision making of the multi-agentbased supply chain system. Ivanov and Dolgui [101] identified three major areas of digital 
twin-enabled supply chain disruption risk management: disruption identification, disruption modeling, and disruption impact assessment and illustrated the use of digital twin as a prescriptive model for decision-making in SCM.

Zhan and Tan [102] proposed an integrated infrastructure for breaking down the information silos and enhancing supply chain performance. Applying deduction graph model, data visualization, and optimization to a sports equipment manufacturer, they showcased the usefulness of the analytic infrastructure for new product development. Kim et al. [103] presented a PRocess ANAlytics System (PRANAS) to effectively and efficiently evaluate the operational performance of supply chains with the use of process cubes, process warehouses, process analytics, data analytics, and hybrid analytics. Er Kara et al. [104] presented a supply chain risk management framework supported by data mining tools / techniques for the identification, assessment, and mitigation of different types of supply chain risks and demonstrated the use of the framework in discovering hidden and useful information from unstructured risk data.

\section{Future Research Directions}

This section attempts to answer RQ5: What are the research opportunities and directions for BDA in SCM? Based on the analysis of mainstream research and practices in the field of BDA in SCM, we identified somewhat understudied but important research opportunities for the further development of BDA in SCM: techniques, types of analytics, security and privacy, alternative theoretical perspectives, and inter-organizational big data analytics.

\subsection{Techniques}

Our research has demonstrated that researchers have used a wide variety of data analytics techniques in big data analytics in the supply chain management arena. For example, Yudhistyra et al. [13] found a wide variety of BDA techniques used in prior research, and the level of use of these techniques too differed between SCM and logistics journals publications. However, Aamer et al. [15], in their review of big data analytics, especially machine learning in demand forecasting, found that though there were many techniques used and neural networks/artificial neural networks were used in almost half of the studies they reviewed. Hence, there are differences in the use of BDA techniques between SCM's sub-areas and within particular techniques in BDA. Therefore, assuming BDA as a single stream of research with specific analytics techniques may hide the individual nuances between the disparate areas of SCM or BDA techniques.

Moreover, natural language processing and association rule learning techniques are seldom used in the BDA associated with supply chain management [13]. Future research should focus on providing integrated frameworks for the selection and use of BDA techniques. Moreover, this type of research can be quite useful for practitioners as they embark on using BDA techniques for their requirements.

\subsection{Types of Analytics}

Data analytics techniques are classified into descriptive analytics-what is happening, predictive analytics — what will be happening, and prescriptive analytics - what should be happening [105]. According to a review [106], predictive and prescriptive analytics are examined more often in the logistics and supply chain management areas. Likewise, Nguyen et al. [7] found prescriptive analytics to be prominent in sub-areas of supply chain and logistics, such as manufacturing, logistics, and transportation. Moreover, a recent review article in the supply chain management research on big data analytics found an increasing focus on predictive analytics when compared to other analytics techniques [107]. The different analytics techniques are also related in terms of phases in which they are carried out and the resultant business value [108]. With disparate analytics techniques available in the SCM areas, future research should examine the implications in the use of these analytics techniques with regard to their performance to yield desired results. For 
example, future research can examine the comparison between benchmark performance and the proposed prescriptive analytics results.

\subsection{Security and Privacy}

This study found that security and privacy considerations are not researched that much concerning $\mathrm{BDA}$ in SCM. Our research findings support the contention of Ogbuke et al. [14] that security, privacy, and ethical issues are underexplored in the BDA in the SCM area. The importance of data security in supply chain management is increasing. For example, various emerging technologies, such as blockchain, IoT, and machine learning are increasingly used in the global supply chains and require transparency, security, and trustworthiness [109]. The seamless flow of data and the resultant analytics capabilities of the supply chain partners require robust security considerations. Future research in these concepts is vitally important, as organizations increasingly rely on BDA with large sensitive datasets. Likewise, privacy is another consideration that needs greater exploration concerning BDA in the SCM area. For example, the European General Data Protection Regulation has an impact on digitalized SCM and the use and access of data [110]. Hence, future research examining the regulations and their impact on BDA is vitally important.

\subsection{Alternative Theoretical Perspectives}

One of the streams of research in BDA is the study of its effects on organizational performance. Hence, researchers examining the effects of SCM BDA on firm performance have used the dynamic capabilities to a great extent. Dynamic capabilities are organizational and strategic routines by which firms achieve new resource configurations [39]. For example, Bahrami and Shokouhyar [111] used the dynamic capabilities perspective to study the effect of BDA on supply chain resilience and firm performance.

A recent bibliometric study on BDA highlights that dynamic capabilities are used widely to study BDA on organizations and supply chain management is no exception [112]. However, other alternative perspectives could also be explored. For example, Grover et al. [113], in their research on value creation using BDA in businesses, highlight various theoretical logics, a resource-based view, strategic-IT alignment, real options thinking, and absorptive capacity to add perspectives on the value creation. Hence, future research using multiple frameworks can better capture the role of BDA in the SCM area.

\subsection{Inter-Organizational Big Data Analytics}

Bala and Venkatesh [114] highlight that much of SCM research has been at the organizational level with little or no research on the process, standards, and analytics capabilities at the employee level. In a similar vein, BDA needs to be examined at the inter-organizational level. Current research on BDA in the supply chain is focused on organizational performance. For example, Oncioiu et al. [115] examine the impact of BDA on company performance. However, supply chains are inherently inter-organizational, and the analytics used in such inter-organizational context needs examination. In a recent study of interorganizational relationships, Browder et al. [116] state that BDA innovation process logic to be different with a focus on creating value through collective experimentation. Hence, future research is needed to further examine the value creation and business value of BDA with inter-organizational perspectives. For example, inter-organizational BDA's impact on sustainability and organizational performance can be examined.

\section{Conclusions}

Supply chain management has become a critical component in the functioning of global economies. Recent events, such as the ongoing pandemic, have increased supply chain uncertainties [117]. These intrinsic (e.g., port bottlenecks, container shortages) and extraneous (e.g., parts shortage, demand surges) factors have accentuated the uncertainties in supply chain management, furthering the importance of BDA in SCM. BDA plays a vital role in the functioning of SCM through various means, such as handling customer 
preference changes, visibility improvements, and resilience. Due to this, there is a burgeoning interest for BDA in SCM for both practitioners (e.g., [5]) and academicians (surge in research publications). As with the case of research in the SCM area [6], an interdisciplinary perspective is needed to gain an increased understanding of BDA in SCM research. Though there exist quite a few literature reviews on BDA in SCM [7-16], there is a lack of an interdisciplinary focus in the prior works.

In this context, this study's goal is to review the literature on BDA in SCM using the systematic literature review method [17] and address the presented research questions using an interdisciplinary perspective. Towards this end, this study cast a wide net to identify suitable BDA research in SCM, including technical and business-oriented journals. For the top-down approach, we used the details of 389 research articles and conducted the cooccurrence analysis of keywords. This analysis identified the major research themes of the extant research, which included organizational and technical perspectives. Subsequently, we examined a select list of 60 articles based on pre-defined inclusion/exclusion criteria for the bottom-up approach to gain a deeper and richer perspective on the existing research. Hence, this study's findings uniquely complement prior literature reviews in BDA in SCM.

This study uses cross-cutting themes (e.g., theoretical underpinnings, SCOR processes, types of analytics, etc.) to situate the findings on both organizational and technical perspectives in BDA research in SCM. Moreover, this study relied on both the bottom-up approach (classifying studies based on bibliometric analysis) and the top-down approach (using a framework to classify the findings). Some of the salient findings of this study include the identification of prominent theories used in the study of BDA in SCM. For example, the dynamic capabilities view is one of the overwhelmingly used theories to study organizational performances and sustainability. Predictive analytics is examined predominantly in our sample of studies. These findings reaffirm prior research that found a preponderance of dynamic capabilities view [112] and predictive analytics [107] in BDA in SCM research.

Our focus on sustainability within BDA in SCM research provides a unique perspective on our knowledge, as previous literature reviews on BDA in SCM did not explicitly focus on it (e.g., [118]). Sustainability in SCM is an important area of consideration due to its multi-faceted impacts on the organization and the world. Our findings highlight the use of theories, such as the stakeholder theory, in prior research on sustainability. Our study also showcases the use of BDA in SCM in the context of SCOR models and provides an updated view of existing literature, and complements the past findings of research reviews [10].

This study identified gaps and provided ideas for future research based on the review findings in alternative theoretical perspectives and analytical methods. Moreover, a paucity of studies explored the inter-organizational perspective apparent in the review. With SCM being innately inter-organizational, future research can focus on the role of BDA in such contexts. With SCM and BDA becoming increasingly prominent in recent years, this timely study adds to the current understanding of BDA in SCM research by identifying salient aspects from both organizational and technical perspectives.

Author Contributions: Conceptualization: I.L.; investigation: I.L. and G.M.; methodology: I.L. and G.M.; writing: I.L. and G.M. All authors have read and agreed to the published version of the manuscript.

Funding: This research received no external funding.

Institutional Review Board Statement: Not applicable.

Informed Consent Statement: Not applicable.

Data Availability Statement: Not applicable.

Conflicts of Interest: The authors declare no conflict of interest. 


\section{References}

1. Davenport, T.H. Big Data at Work: Dispelling the Myths, Uncovering the Opportunities, Illustrated ed.; Harvard Business Review Press: Boston, MA, USA, 2014.

2. Hassani, H.; Unger, S.; Beneki, C. Big Data and Actuarial Science. Big Data Cogn. Comput. 2020, 4, 40. [CrossRef]

3. Miles, R.E.; Snow, C.C. Organization theory and supply chain management: An evolving research perspective. J. Oper. Manag. 2006, 25, 459-463. [CrossRef]

4. Patnayakuni, R.; Rai, A.; Seth, N. Relational Antecedents of Information Flow Integration for Supply Chain Coordination. J. Manag. Inf. Syst. 2006, 23, 13-49. [CrossRef]

5. Big Data Market by Solutions \& Services-2025 I MarketsandMarkets. Available online: https://www.marketsandmarkets.com/ Market-Reports/big-data-market-1068.html (accessed on 20 December 2021).

6. Sanders, N.R.; Zacharia, Z.G.; Fugate, B.S. The Interdisciplinary Future of Supply Chain Management Research. Decis. Sci. 2013, 44, 413-429. [CrossRef]

7. Van Nguyen, T.; Zhou, L.; Spiegler, V.; Ieromonachou, P.; Lin, Y. Big data analytics in supply chain management: A state-of-the-art literature review. Comput. Oper. Res. 2018, 98, 254-264. [CrossRef]

8. Tiwari, S.; Wee, H.M.; Daryanto, Y. Big data analytics in supply chain management between 2010 and 2016: Insights to industries. Comput. Ind. Eng. 2018, 115, 319-330. [CrossRef]

9. Ardito, L.; Scuotto, V.; Del Giudice, M.; Petruzzelli, A.M. A bibliometric analysis of research on Big Data analytics for business and management. Manag. Decis. 2019, 57, 1993-2009. [CrossRef]

10. Chehbi-Gamoura, S.; Derrouiche, R.; Damand, D.; Barth, M. Insights from big Data Analytics in supply chain management: An all-inclusive literature review using the SCOR model. Prod. Plan. Control 2019, 31, 355-382. [CrossRef]

11. Inamdar, Z.; Raut, R.; Narwane, V.S.; Gardas, B.; Narkhede, B.; Sagnak, M. A systematic literature review with bibliometric analysis of big data analytics adoption from period 2014 to 2018. J. Enterp. Inf. Manag. 2020, 34, 101-139. [CrossRef]

12. Kamble, S.S.; Gunasekaran, A. Big data-driven supply chain performance measurement system: A review and framework for implementation. Int. J. Prod. Res. 2019, 58, 65-86. [CrossRef]

13. Yudhistyra, W.; Risal, E.M.; Raungratanaamporn, I.-S.; Ratanavaraha, V. Exploring Big Data Research: A Review of Published Articles from 2010 to 2018 Related to Logistics and Supply Chains. Oper. Supply Chain Manag. Int. J. 2020, 13, 134-149. [CrossRef]

14. Ogbuke, N.J.; Yusuf, Y.Y.; Dharma, K.; Mercangoz, B.A. Big data supply chain analytics: Ethical, privacy and security challenges posed to business, industries and society. Prod. Plan. Control 2022, 33, 123-137. [CrossRef]

15. Aamer, A.; Yani, L.P.E.; Priyatna, I.M.A. Data Analytics in the Supply Chain Management: Review of Machine Learning Applications in Demand Forecasting. Oper. Supply Chain Manag. Int. J. 2020, 14, 1-13. [CrossRef]

16. Maheshwari, S.; Gautam, P.; Jaggi, C.K. Role of Big Data Analytics in supply chain management: Current trends and future perspectives. Int. J. Prod. Res. 2021, 59, 1875-1900. [CrossRef]

17. Denyer, D.; Tranfield, D. Producing a systematic review. In The Sage Handbook of Organizational Research Methods; Sage Publications Ltd.: Thousand Oaks, CA, USA, 2009; pp. 671-689.

18. Arunachalam, D.; Kumar, N.; Kawalek, J.P. Understanding big data analytics capabilities in supply chain management: Unravelling the issues, challenges and implications for practice. Transp. Res. Part E Logist. Transp. Rev. 2018, 114, 416-436. [CrossRef]

19. Chaudhuri, A.; Dukovska-Popovska, I.; Subramanian, N.; Chan, H.K.; Bai, R. Decision-making in cold chain logistics using data analytics: A literature review. Int. J. Logist. Manag. 2018, 29, 839-861. [CrossRef]

20. Naz, F.; Kumar, A.; Majumdar, A.; Agrawal, R. Is artificial intelligence an enabler of supply chain resiliency post COVID-19? An exploratory state-of-the-art review for future research. Oper. Manag. Res. 2021, 1-21. [CrossRef]

21. Denyer, D.; Tranfield, D.; van Aken, J.E. Developing Design Propositions through Research Synthesis. Organ. Stud. 2008, 29, 393-413. [CrossRef]

22. Chen, D.Q.; Preston, D.S.; Swink, M. How the Use of Big Data Analytics Affects Value Creation in Supply Chain Management. J. Manag. Inf. Syst. 2015, 32, 4-39. [CrossRef]

23. Mandal, S. The influence of big data analytics management capabilities on supply chain preparedness, alertness and agility: An empirical investigation. Inf. Technol. People 2019, 32, 297-318. [CrossRef]

24. Wamba, S.F.; Dubey, R.; Gunasekaran, A.; Akter, S. The performance effects of big data analytics and supply chain ambidexterity: The moderating effect of environmental dynamism. Int. J. Prod. Econ. 2020, 222, 107498. [CrossRef]

25. Bamel, N.; Bamel, U. Big data analytics based enablers of supply chain capabilities and firm competitiveness: A fuzzy-TISM approach. J. Enterp. Inf. Manag. 2020, 34, 559-577. [CrossRef]

26. Dubey, R.; Gunasekaran, A.; Childe, S.J. Big data analytics capability in supply chain agility: The moderating effect of organizational flexibility. Manag. Decis. 2019, 57, 2092-2112. [CrossRef]

27. Gu, V.C.; Zhou, B.; Cao, Q.; Adams, J. Exploring the relationship between supplier development, big data analytics capability, and firm performance. Ann. Oper. Res. 2021, 302, 151-172. [CrossRef]

28. Singh, N.P.; Singh, S. Building supply chain risk resilience: Role of big data analytics in supply chain disruption mitigation. Benchmarking Int. J. 2019, 26, 2318-2342. [CrossRef]

29. Srinivasan, R.; Swink, M. An Investigation of Visibility and Flexibility as Complements to Supply Chain Analytics: An Organizational Information Processing Theory Perspective. Prod. Oper. Manag. 2018, 27, 1849-1867. [CrossRef] 
30. Yu, W.; Zhao, G.; Liu, Q.; Song, Y. Role of big data analytics capability in developing integrated hospital supply chains and operational flexibility: An organizational information processing theory perspective. Technol. Forecast. Soc. Chang. 2021, 163, 120417. [CrossRef]

31. Roßmann, B.; Canzaniello, A.; von der Gracht, H.; Hartmann, E. The future and social impact of Big Data Analytics in Supply Chain Management: Results from a Delphi study. Technol. Forecast. Soc. Chang. 2018, 130, 135-149. [CrossRef]

32. Gunasekaran, A.; Papadopoulos, T.; Dubey, R.; Wamba, S.F.; Childe, S.J.; Hazen, B.; Akter, S. Big data and predictive analytics for supply chain and organizational performance. J. Bus. Res. 2017, 70, 308-317. [CrossRef]

33. Shafique, M.N.; Khurshid, M.M.; Rahman, H.; Khanna, A.; Gupta, D. The Role of Big Data Predictive Analytics and Radio Frequency Identification in the Pharmaceutical Industry. IEEE Access 2019, 7, 9013-9021. [CrossRef]

34. Fernando, Y.; Chidambaram, R.R.; Wahyuni-Td, I.S. The impact of Big Data analytics and data security practices on service supply chain performance. Benchmarking Int. J. 2018, 25, 4009-4034. [CrossRef]

35. Dennehy, D.; Oredo, J.; Spanaki, K.; Despoudi, S.; Fitzgibbon, M. Supply chain resilience in mindful humanitarian aid organizations: The role of big data analytics. Int. J. Oper. Prod. Manag. 2021, 41, 1417-1441. [CrossRef]

36. Lin, C.; Lin, M. Application of Big Data in a Multicategory Product-Service System for Global Logistics Support. IEEE Eng. Manag. Rev. 2019, 47, 108-118. [CrossRef]

37. Jha, A.K.; Agi, M.A.; Ngai, E.W. A note on big data analytics capability development in supply chain. Decis. Support Syst. 2020, 138, 113382. [CrossRef]

38. Teece, D.J.; Pisano, G.; Shuen, A. Dynamic capabilities and strategic management. Strateg. Manag. J. 1997, 18, 509-533. [CrossRef]

39. Eisenhardt, K.M.; Martin, J.A. Dynamic capabilities: What are they? Strateg. Manag. J. 2000, 21, 1105-1121. [CrossRef]

40. Galbraith, J.R. Organization Design: An Information Processing View. INFORMS J. Appl. Anal. 1974, 4, 28-36. [CrossRef]

41. Thomas, J.B.; Clark, S.M.; Gioia, D.A. Strategic Sensemaking and Organizational Performance: Linkages Among Scanning, Interpretation, Action, and Outcomes. Acad. Manag. J. 1993, 36, 239-270. [CrossRef]

42. Galbraith, J.R. Organizational Design Challenges Resulting From Big Data. J. Organ. Des. 2014, 3, 2-13. [CrossRef]

43. Barney, J. Firm Resources and Sustained Competitive Advantage. J. Manag. 1991, 17, 99-120. [CrossRef]

44. Sirmon, D.G.; Hitt, M.A.; Ireland, R.D.; Gilbert, B.A. Resource Orchestration to Create Competitive Advantage: Breadth, Depth, and Life Cycle Effects. J. Manag. 2011, 37, 1390-1412. [CrossRef]

45. Barney, J.B. Strategic Factor Markets: Expectations, Luck, and Business Strategy. Manag. Sci. 1986, 32, 1231-1241. [CrossRef]

46. Wernerfelt, B. A resource-based view of the firm. Strat. Manag. J. 1984, 5, 171-180. [CrossRef]

47. Baker, J.; Jones, D.; Cao, Q.; Song, J. Conceptualizing the Dynamic Strategic Alignment Competency. J. Assoc. Inf. Syst. 2011, 12, 299-322. [CrossRef]

48. Seuring, S.; Müller, M. Core issues in sustainable supply chain management-A Delphi study. Bus. Strat. Environ. 2008, 17, 455-466. [CrossRef]

49. Carter, C.R.; Rogers, D.S. A framework of sustainable supply chain management: Moving toward new theory. Int. J. Phys. Distrib. Logist. Manag. 2008, 38, 360-387. [CrossRef]

50. Dubey, R.; Gunasekaran, A.; Childe, S.J.; Papadopoulos, T.; Luo, Z.; Wamba, S.F.; Roubaud, D. Can big data and predictive analytics improve social and environmental sustainability? Technol. Forecast. Soc. Chang. 2019, 144, 534-545. [CrossRef]

51. Bag, S.; Wood, L.C.; Xu, L.; Dhamija, P.; Kayikci, Y. Big data analytics as an operational excellence approach to enhance sustainable supply chain performance. Resour. Conserv. Recycl. 2020, 153, 104559. [CrossRef]

52. Singh, S.K.; El-Kassar, A.-N. Role of big data analytics in developing sustainable capabilities. J. Clean. Prod. 2019, $213,1264-1273$. [CrossRef]

53. Stekelorum, R.; Laguir, I.; Lai, K.-H.; Gupta, S.; Kumar, A. Responsible governance mechanisms and the role of suppliers' ambidexterity and big data predictive analytics capabilities in circular economy practices improvements. Transp. Res. Part $E$ Logist. Transp. Rev. 2021, 155, 102510. [CrossRef]

54. Wang, C.; Zhang, Q.; Zhang, W. Corporate social responsibility, Green supply chain management and firm performance: The moderating role of big-data analytics capability. Res. Transp. Bus. Manag. 2020, 37, 100557. [CrossRef]

55. Gupta, S.; Chen, H.; Hazen, B.T.; Kaur, S.; Gonzalez, E.D.R.S. Circular economy and big data analytics: A stakeholder perspective. Technol. Forecast. Soc. Chang. 2019, 144, 466-474. [CrossRef]

56. Bag, S.; Pretorius, J.H.C.; Gupta, S.; Dwivedi, Y.K. Role of institutional pressures and resources in the adoption of big data analytics powered artificial intelligence, sustainable manufacturing practices and circular economy capabilities. Technol. Forecast. Soc. Chang. 2021, 163, 120420. [CrossRef]

57. AlNuaimi, B.K.; Khan, M.; Ajmal, M.M. The role of big data analytics capabilities in greening e-procurement: A higher order PLS-SEM analysis. Technol. Forecast. Soc. Chang. 2021, 169, 120808. [CrossRef]

58. Mani, V.; Delgado, C.; Hazen, B.T.; Patel, P. Mitigating Supply Chain Risk via Sustainability Using Big Data Analytics: Evidence from the Manufacturing Supply Chain. Sustainability 2017, 9, 608. [CrossRef]

59. Benzidia, S.; Makaoui, N.; Bentahar, O. The impact of big data analytics and artificial intelligence on green supply chain process integration and hospital environmental performance. Technol. Forecast. Soc. Chang. 2021, 165, 120557. [CrossRef]

60. Raut, R.D.; Mangla, S.K.; Narwane, V.S.; Dora, M.; Liu, M. Big Data Analytics as a mediator in Lean, Agile, Resilient, and Green (LARG) practices effects on sustainable supply chains. Transp. Res. Part E Logist. Transp. Rev. 2021, 145, 102170. [CrossRef] 
61. Kazancoglu, Y.; Pala, M.O.; Sezer, M.D.; Luthra, S.; Kumar, A. Drivers of implementing Big Data Analytics in food supply chains for transition to a circular economy and sustainable operations management. J. Enterp. Inf. Manag. 2021; ahead of print. [CrossRef]

62. Bag, S.; Gupta, S.; Wood, L. Big data analytics in sustainable humanitarian supply chain: Barriers and their interactions. Ann. Oper. Res. 2020, 1-40. [CrossRef]

63. Khan, O.; Daddi, T.; Iraldo, F. The role of dynamic capabilities in circular economy implementation and performance of companies. Corp. Soc. Responsib. Environ. Manag. 2020, 27, 3018-3033. [CrossRef]

64. Freeman, R.E. Strategic Management: A Stakeholder Approach; Cambridge University Press: Cambridge, UK, 2010.

65. Phillips, R. Stakeholder Theory and Organizational Ethics; Berrett-Koehler Publishers: San Francisco, CA, USA, 2003.

66. Hasan, I.; Kobeissi, N.; Liu, L.; Wang, H. Corporate Social Responsibility and Firm Financial Performance: The Mediating Role of Productivity. J. Bus. Ethic 2018, 149, 671-688. [CrossRef]

67. Lai, Y.; Sun, H.; Ren, J. Understanding the determinants of big data analytics (BDA) adoption in logistics and supply chain management: An empirical investigation. Int. J. Logist. Manag. 2018, 29, 676-703. [CrossRef]

68. Khan, M. Challenges with big data analytics in service supply chains in the UAE. Manag. Decis. 2019, 57, 2124-2147. [CrossRef]

69. Kusi-Sarpong, S.; Orji, I.J.; Gupta, H.; Kunc, M. Risks associated with the implementation of big data analytics in sustainable supply chains. Omega 2021, 105, 102502. [CrossRef]

70. Kache, F.; Seuring, S. Challenges and opportunities of digital information at the intersection of Big Data Analytics and supply chain management. Int. J. Oper. Prod. Manag. 2017, 37, 10-36. [CrossRef]

71. Moktadir, A.; Ali, S.M.; Paul, S.K.; Shukla, N. Barriers to big data analytics in manufacturing supply chains: A case study from Bangladesh. Comput. Ind. Eng. 2019, 128, 1063-1075. [CrossRef]

72. Raut, R.D.; Yadav, V.S.; Cheikhrouhou, N.; Narwane, V.S.; Narkhede, B.E. Big data analytics: Implementation challenges in Indian manufacturing supply chains. Comput. Ind. 2021, 125, 103368. [CrossRef]

73. Brandtner, P.; Darbanian, F.; Falatouri, T.; Udokwu, C. Impact of COVID-19 on the Customer End of Retail Supply Chains: A Big Data Analysis of Consumer Satisfaction. Sustainability 2021, 13, 1464. [CrossRef]

74. Egilmez, G.; Ghani, N.M.A.M.A.; Gedik, R. Layer analysis of $\mathrm{CO}_{2}$ sources in the US economic supply chains: An input output LCA study. Ind. Manag. Data Syst. 2017, 117, 2171-2193. [CrossRef]

75. Chae, B. Insights from hashtag \#supplychain and Twitter Analytics: Considering Twitter and Twitter data for supply chain practice and research. Int. J. Prod. Econ. 2015, 165, 247-259. [CrossRef]

76. Keller, T.; Thiesse, F.; Fleisch, E. Classification Models for RFID-Based Real-Time Detection of Process Events in the Supply Chain: An Empirical Study. ACM Trans. Manag. Inf. Syst. 2015, 5, 1-30. [CrossRef]

77. Kinra, A.; Hald, K.S.; Mukkamala, R.R.; Vatrapu, R. An unstructured big data approach for country logistics performance assessment in global supply chains. Int. J. Oper. Prod. Manag. 2020, 40, 439-458. [CrossRef]

78. Wang, F.; Ding, L.; Yu, H.; Zhao, Y. Big data analytics on enterprise credit risk evaluation of e-Business platform. Inf. Syst. e-Bus. Manag. 2020, 18, 311-350. [CrossRef]

79. Yeboah-Ofori, A.; Islam, S.; Lee, S.W.; Shamszaman, Z.U.; Muhammad, K.; Altaf, M.; Al-Rakhami, M.S. Cyber Threat Predictive Analytics for Improving Cyber Supply Chain Security. IEEE Access 2021, 9, 94318-94337. [CrossRef]

80. Scheidt, S.; Chung, Q. Making a case for speech analytics to improve customer service quality: Vision, implementation, and evaluation. Int. J. Inf. Manag. 2019, 45, 223-232. [CrossRef]

81. Leung, K.; Mo, D.Y.; Ho, G.; Wu, C.; Huang, G. Modelling near-real-time order arrival demand in e-commerce context: A machine learning predictive methodology. Ind. Manag. Data Syst. 2020, 120, 1149-1174. [CrossRef]

82. Iftikhar, R.; Khan, M.S. Social Media Big Data Analytics for Demand Forecasting: Development and case implementation of an innovative framework. J. Glob. Inf. Manag. 2020, 28, 103-120. [CrossRef]

83. Singh, A.; Shukla, N.; Mishra, N. Social media data analytics to improve supply chain management in food industries. Transp. Res. Part E Logist. Transp. Rev. 2018, 114, 398-415. [CrossRef]

84. Sathyan, R.; Parthiban, P.; Dhanalakshmi, R.; Minz, A. A combined big data analytics and Fuzzy DEMATEL technique to improve the responsiveness of automotive supply chains. J. Ambient Intell. Humaniz. Comput. 2021, 12, 7949-7963. [CrossRef]

85. Chang, X.; Huang, Y.; Li, M.; Bo, X.; Kumar, S. Efficient Detection of Environmental Violators: A Big Data Approach. Prod. Oper. Manag. 2021, 30, 1246-1270. [CrossRef]

86. Wang, S.-C.; Tsai, Y.-T.; Ciou, Y.-S. A hybrid big data analytical approach for analyzing customer patterns through an integrated supply chain network. J. Ind. Inf. Integr. 2020, 20, 100177. [CrossRef]

87. Lau, R.Y.K.; Zhang, W.; Xu, W. Parallel Aspect-Oriented Sentiment Analysis for Sales Forecasting with Big Data. Prod. Oper. Manag. 2018, 27, 1775-1794. [CrossRef]

88. Lee, C.K.H. A GA-based optimisation model for big data analytics supporting anticipatory shipping in Retail 4.0. Int. J. Prod. Res. 2017, 55, 593-605. [CrossRef]

89. Zhong, R.Y.; Xu, C.; Chen, C.; Huang, G.Q. Big Data Analytics for Physical Internet-based intelligent manufacturing shop floors. Int. J. Prod. Res. 2017, 55, 2610-2621. [CrossRef]

90. Hassani, H.; Beneki, C.; Unger, S.; Mazinani, M.T.; Yeganegi, M.R. Text Mining in Big Data Analytics. Big Data Cogn. Comput. 2020, 4, 1. [CrossRef]

91. SCOR Model. Available online: https://scor.ascm.org/processes/introduction (accessed on 10 November 2021). 
92. Zhou, H.; Benton, W.C.; Schilling, D.A.; Milligan, G.W. Supply Chain Integration and the SCOR Model. J. Bus. Logist. 2011, 32, 332-344. [CrossRef]

93. Palma-Mendoza, J.A. Analytical hierarchy process and SCOR model to support supply chain re-design. Int. J. Inf. Manag. 2014, 34, 634-638. [CrossRef]

94. Wang, W.Y.; Chan, H.K.; Pauleen, D.J. Aligning business process reengineering in implementing global supply chain systems by the SCOR model. Int. J. Prod. Res. 2010, 48, 5647-5669. [CrossRef]

95. Sundarakani, B.; Razzak, H.A.; Manikandan, S. Creating a competitive advantage in the global flight catering supply chain: A case study using SCOR model. Int. J. Logist. Res. Appl. 2018, 21, 481-501. [CrossRef]

96. Thunberg, M.; Persson, F. Using the SCOR model's performance measurements to improve construction logistics. Prod. Plan. Control 2014, 25, 1065-1078. [CrossRef]

97. Venkatesh, V.G.; Kang, K.; Wang, B.; Zhong, R.Y.; Zhang, A. System architecture for blockchain based transparency of supply chain social sustainability. Robot. Comput. Integr. Manuf. 2020, 63, 101896. [CrossRef]

98. Molka-Danielsen, J.; Engelseth, P.; Wang, H. Large scale integration of wireless sensor network technologies for air quality monitoring at a logistics shipping base. J. Ind. Inf. Integr. 2018, 10, 20-28. [CrossRef]

99. Fernández-Caramés, T.M.; Blanco-Novoa, O.; Froiz-Míguez, I.; Fraga-Lamas, P. Towards an Autonomous Industry 4.0 Warehouse: A UAV and Blockchain-Based System for Inventory and Traceability Applications in Big Data-Driven Supply Chain Management. Sensors 2019, 19, 2394. [CrossRef]

100. Giannakis, M.; Louis, M. A multi-agent based system with big data processing for enhanced supply chain agility. J. Enterp. Inf. Manag. 2016, 29, 706-727. [CrossRef]

101. Ivanov, D.; Dolgui, A. A digital supply chain twin for managing the disruption risks and resilience in the era of Industry 4.0. Prod. Plan. Control 2021, 32, 775-788. [CrossRef]

102. Zhan, Y.; Tan, K.H. An analytic infrastructure for harvesting big data to enhance supply chain performance. Eur. J. Oper. Res. 2020, 281, 559-574. [CrossRef]

103. Kim, A.; Obregon, J.; Jung, J.-Y. PRANAS: A Process Analytics System Based on Process Warehouse and Cube for Supply Chain Management. Appl. Sci. 2020, 10, 3521. [CrossRef]

104. Kara, M.E.; Firat, S.O.; Ghadge, A. A data mining-based framework for supply chain risk management. Comput. Ind. Eng. 2020, 139, 105570. [CrossRef]

105. Souza, G.C. Supply chain analytics. Bus. Horiz. 2014, 57, 595-605. [CrossRef]

106. Mahdiloo, M.; Noorizadeh, A.; Saen, R.F. Big data analytics in logistics and supply chain management: Certain investigations for research and applications. Int. J. Prod. Econ. 2016, 176, 98-110. [CrossRef]

107. Ghalehkhondabi, I.; Ahmadi, E.; Maihami, R. An overview of big data analytics application in supply chain management published in 2010-2019. Production 2020, 30, e20190140. [CrossRef]

108. Lepenioti, K.; Bousdekis, A.; Apostolou, D.; Mentzas, G. Prescriptive analytics: Literature review and research challenges. Int. J. Inf. Manag. 2020, 50, 57-70. [CrossRef]

109. Hassija, V.; Chamola, V.; Gupta, V.; Jain, S.; Guizani, N. A Survey on Supply Chain Security: Application Areas, Security Threats, and Solution Architectures. IEEE Internet Things J. 2021, 8, 6222-6246. [CrossRef]

110. Dasgupta, A.; Gill, A.Q.; Hussain, F. A Review of General Data Protection Regulation for Supply Chain Ecosystem. In Proceedings of the 13th International Conference on Innovative Mobile and Internet Services in Ubiquitous Computing (IMIS-2019), Sydney, Australia, 3-5 July 2019; pp. 456-465. [CrossRef]

111. Bahrami, M.; Shokouhyar, S. The role of big data analytics capabilities in bolstering supply chain resilience and firm performance: A dynamic capability view. Inf. Technol. People, 2021; ahead of print. [CrossRef]

112. Rialti, R.; Marzi, G.; Ciappei, C.; Busso, D. Big data and dynamic capabilities: A bibliometric analysis and systematic literature review. Manag. Decis. 2019, 57, 2052-2068. [CrossRef]

113. Grover, V.; Chiang, R.H.; Liang, T.-P.; Zhang, D. Creating Strategic Business Value from Big Data Analytics: A Research Framework. J. Manag. Inf. Syst. 2018, 35, 388-423. [CrossRef]

114. Bala, H.; Venkatesh, V. Employees' reactions to IT-enabled process innovations in the age of data analytics in healthcare. Bus. Process Manag. J. 2017, 23, 671-702. [CrossRef]

115. Oncioiu, I.; Bunget, O.C.; Türkeș, M.C.; Căpușneanu, S.; Topor, D.I.; Tamas,, A.S.; Rakos, I.-S.; Hint, M. The Impact of Big Data Analytics on Company Performance in Supply Chain Management. Sustainability 2019, 11, 4864. [CrossRef]

116. Browder, R.; Koch, H.; Long, M.A.; Hernandez, J. Learning to Innovate with Big Data Analytics in Inter-Organizational Relationships. Acad. Manag. Discov. 2020, in press. [CrossRef]

117. Paul, S.K.; Chowdhury, P.; Moktadir, A.; Lau, K.H. Supply chain recovery challenges in the wake of COVID-19 pandemic. J. Bus. Res. 2021, 136, 316-329. [CrossRef]

118. Zhang, X.; Yu, Y.; Zhang, N. Sustainable supply chain management under big data: A bibliometric analysis. J. Enterp. Inf. Manag. 2020, 34, 427-445. [CrossRef] 